\title{
The influence of bottom currents on the Zambezi Valley morphology (Mozambique Channel, SW Indian Ocean): In situ current observations and hydrodynamic modelling
}

\author{
Miramontes Elda ${ }^{1,{ }^{*}}$, Penven Pierrick ${ }^{2}$, Fierens Ruth ${ }^{1}$, Droz Laurence ${ }^{1}$, Toucanne Samuel ${ }^{3}$, \\ Jorry Stephan ${ }^{3}$, Jouet Gwenael ${ }^{3}$, Pastor Lucie ${ }^{4}$, Silva Jacinto Ricardo ${ }^{3}$, Gaillot Arnaud ${ }^{3}$, \\ Giraudeau Jacques ${ }^{5}$, Raisson François ${ }^{6}$
}

${ }^{1}$ UMR 6538 CNRS-UBO, IUEM, Laboratoire Géosciences Océan, 29280 Plouzané, France

${ }^{2}$ UMR 6523 CNRS, IFREMER, IRD, UBO, Laboratoire d'Océanographie Physique et Spatiale, Plouzané 29280, France

3 IFREMER, Géosciences Marines, Centre de Brest, 29280 Plouzané, France

${ }^{4}$ IFREMER, Laboratoire Environnement Profond, Centre de Brest, 29280 Plouzané, France

${ }^{5}$ EPOC, UMR 5805, Université de Bordeaux, CNRS, 33615, Pessac CEDEX, France

${ }^{6}$ TOTAL, R\&D Frontier Exploration program, 64000 Pau, France

*Corresponding author : Elda Miramontes, email address : Elda.Miramontesgarcia@univ-brest.fr

\begin{abstract}
:
Mixed turbidite-contourite systems can be found in oceans where bottom currents and turbidity currents interact. The Zambezi turbidite system, located in the Mozambique Channel (SW Indian Ocean), is one of the largest sedimentary systems in the world in length and area of the related catchments. The oceanic circulation in the Mozambique Channel is intense and complex, dominated by eddies flowing southwards and deep currents flowing northwards along the Mozambican margin. Current measurements obtained from moorings at 3400-4050 m water depth in the Zambezi and Tsiribihina valleys show periods of intense currents at the seafloor with peaks of $40-50 \mathrm{~cm} \mathrm{~s}-1$ that last up to one month and are not related to turbidity currents. These strong bottom-current events are correlated with a change in current direction and an increase in temperature. The periods of current intensification may be related to eddies, since they present similar frequencies (around 7 per year). Moreover, modelling results show that during periods of intense deep circulation an anticyclonic eddy is present between the Mozambican slope and the centre of the Mozambique Channel, which may block the northward transport of the deep water mass and thus enhance the southward transport along the western slope of Madagascar. According to our hydrodynamic modelling of the circulation near the seafloor, intense currents are often present along the Zambezi Valley, especially along the valley flanks. Multi-channel seismic reflection data show that the Zambezi turbidite system does not show the typical characteristics of turbidite systems, being dominated by erosional processes, which mainly affect the valley flanks. Levees associated with the valley are absent in the main axis of the system. The effect of bottom currents on sedimentation in the basin is evidenced by the low sedimentation rates that witness winnowing in the basin, the presence of contouritic sand in the Zambezi Valley flanks and the abundance of current-related bedforms observed in multibeam bathymetry and seismic data. The intense oceanic processes observed in the Mozambique Channel may transport a large part of the fine sediment out of the basin and erode the seafloor even at great depths. Therefore, the Zambezi turbidite
\end{abstract}


system could at present be considered as a mixed turbidite-contourite system, with important implications for source-to-sink studies.

\section{Highlights}

- In situ measurements and modelling show strong currents along the Zambezi Valley. Measured bottom currents in the Zambezi and Tsiribihina Valleys reach $53 \mathrm{~cm} \mathrm{~s}^{-1}$. Eddies block the Mozambique Undercurrent, enhancing southward flow along the valley. Bottom currents erode the Zambezi Valley flanks and control its morphology.

Keywords : Contourite, Turbidity current, Mixed system, Oceanic circulation, Mooring, ADCP, ROMS model, Bedform 


\section{Introduction}

The effect of oceanic currents on sediment transfer from the continent to the deep sea has been widely recognised on the continental shelves (e.g., Sømme et al., 2009; Covault et al., 2011). However, in source-to-sink studies, the effect of bottom currents in deep-sea settings has not often been taken into consideration (Calvès et al., 2013). The source-to-sink system is commonly divided into different segments: catchment, continental shelf, slope and basin floor (Sømme et al., 2009; Helland-Hansen et al., 2016; Romans et al., 2016). This vision of the continent-basin transition as a 
continuum does not take into account the complexity and intensity of the oceanic circulation. Bottom currents can generate, for instance, erosion on the slope with the formation of contouritic terraces dominated by erosional processes and coarse-grained sediment (Hernández-Molina et al., 2016; 2017), or alongslope redistribution of the sediment carried by turbidity currents (Mulder et al., 2008). Therefore, in order to take the effect of oceanic circulation on basin sedimentation into account, it is necessary to perform 3D studies of the sedimentary processes acting across- and alongslope.

All turbidite systems can potentially be affected by geostrophic currents because these occur along continental margins worldwide. However, when the energy of sediment gravity flows is high, the influence of bottom currents may become insignificant. Mixed contourite-turbidite systems are developed where bottom currents and gravity-driven processes occur in the same area and have similar energy, resulting in modifications of the sediment body morphology or in alternations of contourites and turbidites (Mulder et al., 2008).

Bottom currents are often considered as permanent steady flows, in contrast to the more episodic nature of gravity-flows (Rebesco et al., 2014). Nevertheless, both short-term and seasonal variations may also be involved in controlling the formation of sediment drifts (Zhang et al., 2016; Thran et al., 2018). More studies based on in situ current measurements and hydrodynamic modelling are needed to better understand the intensity and variability of bottom currents and their effect on deep-sea sedimentation. In order to provide new insights on this topic, we aim to: (i) analyse intensity and temporal variability of the bottom circulation in the Mozambique Channel; and (ii) decipher the impact of such circulation on the development of the Zambezi turbidite system, by comparing the observed and modeled current patterns with the resulting morphology. We used a multidisciplinary approach that integrates multibeam bathymetry, seismic reflection data, sediment cores, mooring data (current velocity, temperature and sediment trap) and hydrodynamic modelling. 


\section{Regional setting}

\subsection{Geological setting}

The Mozambique Channel is an elongate, north-south oriented basin, located in the Southwest Indian Ocean between the African continent and Madagascar. Its depth ranges between $2700 \mathrm{~m}$ in the north at the narrowest part of the channel and $5000 \mathrm{~m}$ in the southern part of the channel (Fig. 1A). The Mozambique Channel developed during the breakup of Gondwana in the Early Jurassic-Early Cretaceous (Mahanjane, 2014; and references therein). A group of modern isolated carbonate platforms is located in the middle of the channel, which includes Bassas da India and Europa (Jorry et al., 2016; Fig. 1B). The study of seamounts at the vicinity of the modern reef has shown that carbonates started to settle on volcanic edifices during Oligocene-Miocene times (Courgeon et al., 2016).

The sedimentary deposits in the Mozambique Channel are bounded in the north and west by the Mozambican margin, and in the east by the Madagascar margin and the Davie Ridge (Castelino et al., 2017). The Zambezi is the main river delivering sediment to the basin, which, with a catchment area of $1.4 \cdot 10^{6} \mathrm{~km}^{2}$ (Walford et al., 2005), is one of the largest fluvial systems in SE Africa. However, some sediment is also supplied from Madagascar, for instance from the Tsiribihina river (Fig. 1B). The modern Zambezi turbidite system started to develop at the beginning of the Oligocene (Droz and Mougenot, 1987). It is composed of two main valleys, the Zambezi Valley originating from the Mozambican margin and the Tsiribihina Valley, which is a tributary originating from the Madagascar margin (Figs. 1B and 2). At present the Zambezi submarine system is not directly connected to the river system (Schulz et al., 2011). The sediment is mainly dispersed by alongshore currents on the continental shelf during sea level high-stands (Schulz et al., 2011; Wiles et al., 2017a).

\subsection{Oceanographic setting}

The oceanic circulation in the Mozambique Channel is very complex and intense. It forms part of the greater Agulhas Current system that extends from north of Madagascar to South Africa (Fig. 1A; 
Lutjeharms, 2006). The Agulhas Current is the strongest western-boundary current in the southern hemisphere, and it is an important link in the heat and salt exchange between the Indian and the Atlantic Oceans (Gordon, 1986; Weijer et al., 1999). Currents in the Mozambique Channel comprise a southward-bound, western boundary current (Mozambique Current, MC) (DiMarco et al., 2002; Quartly et al., 2013; Flemming and Kudrass, 2018) and anticyclonic eddies with diameters of $\geq 300$ $\mathrm{km}$, that flow southwards and can affect the whole water column (Fig. 1A; de Ruijter et al., 2002; Halo et al., 2014). The frequency of the eddy passage is about four to seven per year (Schouten et al., 2003). Eddies trap anomalous water masses with higher nutrient and lower oxygen concentrations (Swart et al., 2010), advect coastal waters with high phytoplankton biomass into the offshore oceanic environment (Tew-Kai and Marsac, 2009), and may also transport sediment in suspension as observed in the South China Sea (Zhang et al., 2014). The formation of eddies in the Mozambique Channel is related to the South Equatorial Current (SEC) (Fig. 1A; Schott et al., 2009). The SEC splits near $17^{\circ} \mathrm{S}$ into two branches, the Northeast and Southeast Madagascar Currents (NEMC and SEMC) (Fig. 1A; Schott et al., 2009).

The upper layers of the Mozambique Channel are composed of the Tropical Surface Water (TSW) at the surface and the Subtropical Surface Water (STSW) in the subsurface. The permanent thermocline is mainly composed of South Indian Central Water (SICW) (Figs. 1C, D). Intermediate waters in the Mozambique Channel are composed of Red Sea Water (RSW), that enters into the Mozambique Channel from the north, and Antarctic Intermediate Water (AAIW), that enters from the south as part of the Mozambique Undercurrent (MUC) (Fig. 1; Ullgren et al., 2012). The deep waters in the Mozambique Channel contain North Atlantic Deep Water (NADW) and Antarctic Bottom Water (AABW) (Figs. 1C, D; van Aken et al., 2004; Ullgren et al., 2012). The NADW is found between about 2000 and $3500 \mathrm{~m}$ water depth (wd) and the AABW at more than $3500 \mathrm{~m}$ wd (Figs. 1C, D). The NADW is characterised by a relative maximum in salinity and oxygen at about $2500 \mathrm{~m}$ wd (Fig. 1D; Mantyla and Reid, 1995). The upper portions of the NADW and the AAIW flow, as the Mozambique Undercurrent (MUC), northwards along the western margin of the basin through the sill of the 
Mozambique Channel (Fig. 1A; van Aken et al., 2004; Ullgren et al., 2012). The deep portion of the NADW and the AABW (characterised by an absolute minimum of temperature and a relative minimum of salinity; Fig. 1D) are constrained by the bathymetry, flowing northwards along the Mozambican margin and back southwards along the eastern part (along Madagascar) (Fig. 1A; van Aken et al., 2004).

\section{Material and methods}

The bathymetry used for this study (Figs. $1 \mathrm{~A}, \mathrm{~B}$ and 2 ) is a compilation of GEBCO bathymetry (GEBCO_08, version 2010-09-27, http://www.gebco.net), with a 30 arc-second resolution, and the multibeam bathymetry of the PAMELA project surveys PTOLEMEE (2014, R/V L'Atalante; Jorry, 2014), PAMELA-MOZ01 (2014, R/V L'Atalante; Olu, 2014), PAMELA-MOZ02 (2015, R/V L'Atalante, Robin and Droz, 2014) and PAMELA-MOZ04 (2015, R/V Pourquoi pas?; Jouet and Deville, 2015), with a horizontal resolution of $30-40 \mathrm{~m}$.

In this study we used 24-channel mini GI-gun seismic reflection data acquired during the PTOLEMEE, PAMELA-MOZO2 and PAMELA-MOZO4 surveys. We used two sediment piston cores (MOZO2-KS06 and MOZO2-KSO7) to show the sedimentary facies of the current-controlled deposits, collected during the PAMELA-MOZO2 survey. The age of core MOZO2-KSO6 has been estimated using biohorizons as defined by first and last occurrences of calcareous nannofossil species (Thierstein et al., 1977; Sato et al., 1991; Reale and Monechi, 2005), as well as by dominance intervals within this group of single species/taxonomical categories according to Pujos (1988), Weaver (1993), and Giraudeau et al. (1998). The top of cores MOZ02-KSO6 and MOZ02-KSO7 were dated using radiocarbon analyses on bulk planktonic foraminifera performed at Beta Analytic laboratories. Radiocarbon ages were calibrated using the Marine13 calibration curve (Reimer et al., 2013). Average sedimentation rates for the last 248-718 kyr were obtained from age models based on radiocarbon dating and $\delta^{18} \mathrm{O}$ isotope correlation (Fierens et al., 2017) of seven cores collected during cruises PAMELA-MOZ01, PAMELA-MOZO2 and PAMELA-MOZ04. Further analysis of the split cores consisted 
on the acquisition of real colour photographs, grain size measurements (every $5 \mathrm{~cm}$ ) using a Malvern 136 Mastersizer 3000 laser diffraction particle size analyser, and analysis of the bulk sediment semiquantitative geochemical composition using an Avaatech X-ray fluorescence (XRF) core scanner. Hydrographic data (Conductivity, Temperature and Depth, CTD profiles) were obtained from the World Ocean Database 2013 (WOD13; https://www.nodc.noaa.gov/OC5/WOD13/) and the Coriolis Database (http://www.coriolis.eu.org/), and used to identify the water masses present near the Zambezi Valley.

During the PAMELA-MOZ01 survey, three moorings (MLP2, MLP3 and MLP5; Fig. 2) were deployed in November 2014 in the Zambezi and Tsiribihina Valleys and were recovered in December 2015 during the PAMELA-MOZ04 survey. At the same time, two more moorings (MLP8 and MLP10; Fig. 2) were deployed in the Zambezi Valley and recovered in January 2017 during the PAMELA-MOZ08 survey (R/V Antea; Khripounoff, 2017). The moorings were located at water depths that range between 3415 and $4054 \mathrm{~m}$ (Fig. 2). They were thus under the influence of the upper part of the AABW and of the mixing zone with the NADW (Figs. 1C, D). With the exception of mooring MLP5, they all consisted of a sediment trap located at $40 \mathrm{~m}$ above the seafloor, a HOBO temperature sensor and a downward looking $307 \mathrm{kHz}$ ADCP located $30 \mathrm{~m}$ above the seafloor. MLP5 consisted of a $614 \mathrm{kHz}$ ADCP mounted $22 \mathrm{~m}$ above the seafloor.

The Regional Ocean Modelling System (ROMS, here the version CROCO: https://www.crocoocean.org/) was used to simulate the bottom circulation at a regional scale with a resolution of $1 / 36^{\circ}$ ( $\sim 3 \mathrm{~km})$. The simulations extended from 1993 to 2014. ROMS is a primitive equation model that can realistically resolve basin-scale, regional and coastal oceanic processes at high resolution (Shchepetkin and McWilliams, 2005). High resolution is here attained by three levels of nested grids, communicating between each other (Debreu et al., 2012). ROMS has a free surface and uses a $\sigma$ topography following vertical grid. The model successfully resolves mesoscale eddies in the Mozambique Channel (Halo et al., 2014). The bathymetry used in the model is GEBCO 2014 (Weatherall et al., 2014) smoothed for numerical constraints. 
We used maps of Sea Level Anomalies (SLA) in order to link the observed changes in current velocity with mesoscale features in the Mozambique Channel. The Ssalto/Duacs SLA heights (MSLA-H) were produced and distributed by the Copernicus Marine and Environment Monitoring Service (CMEMS) (http://www.marine.copernicus.eu).

\section{Results}

\subsection{Bottom currents in the Mozambique Channel}

\subsubsection{In situ current observations in the Zambezi and Tsiribihina Valleys}

Five moorings were deployed in the Zambezi system during two years: (i) from October 2014 to December 2015 in the Zambezi Valley $80 \mathrm{~km}$ upstream and $210 \mathrm{~km}$ downstream of the confluence with the Tsiribihina Valley (MLP2 and MLP5, respectively), and in the Tsiribihina valley $95 \mathrm{~km}$ upstream of the confluence (MLP3); (ii) from December 2015 to January 2017 close to the valley confluence (MLP8) and $210 \mathrm{~km}$ downstream of the confluence (MLP10) (Figs. 2 and 3). Currents near the seafloor show different directions depending on their location, but they often follow a direction similar to the valley axis (Fig. 4). South of the confluence, moorings MLP5 and MLP10 mainly recorded northward currents (Fig. 4). The other three sites, by contrast, show mainly southward currents, with large inversions towards the N-NE, which are particularly remarkable at sites MLP2 and MLP8 (Fig. 4). The periods of S-SSW direction correspond to periods of higher current speed (Fig. 4). Rose diagrams of sites MLP5 and MLP10 show a wider range of current direction at sites MLP3, MLP2 and MLP8 (Fig. 4). Currents at sites MLP5 and MLP10 are less constrained by the valley morphology. In this area, the Zambezi U-shaped thalweg is lower, resulting in a less confined valley and hence a lower impact on the bottom circulation (Fig. 3).

Current speed near the seafloor is very intense at all the studied sites (Fig. 5), reaching up to $53 \mathrm{~cm} \mathrm{~s}$

${ }^{1}$. Upstream and close to the confluence, sites MLP2 and MLP8 registered mean speeds of the available data set of 13 and $15 \mathrm{~cm} \mathrm{~s}^{-1}$, and maximum speeds of $51 \mathrm{~cm} \mathrm{~s}^{-1}$; while at site MLP3 in the Tsiribihina Valley a mean speed of $9 \mathrm{~cm} \mathrm{~s}^{-1}$ and a maximum speed of $38 \mathrm{~cm} \mathrm{~s}^{-1}$ were registered. 
Downstream of the confluence, moorings MLP5 and MLP10 registered mean speeds of 7 and $11 \mathrm{~cm} \mathrm{~s}$ 1, and maximum speeds of 37 and $53 \mathrm{~cm} \mathrm{~s}^{-1}$, respectively (Fig. 5). The currents show periods of intensified circulation, especially at sites MLP2 and MLP8, that can last up to one month (Fig. 5). These periods of intense bottom currents are coincident with a change in current direction and an increase in temperature (Fig. 6). The high frequency variability observed in the current data (Figs. 5 and 6) is related to tides. At site MLP8, the current direction is generally NNE when the currents are weaker, while during the periods of intense circulation the direction reverses to SSW (Figs. 5 and 6). These events of intense circulation are not related to turbidity currents because there is no correlation between the current speed and the sediment flux obtained from a sediment trap (Fig. 6). The measured sediment flux is usually low during the periods of strong currents, for instance during December 2015-January 2016, April-May 2016 or August 2016. Miramontes et al. (accepted) also observed reduced sedimentation from turbidity measurements during periods of intense currents on the Hall seamount located in the centre of the Mozambique Channel (Fig. 1B).

\subsubsection{Simulated bottom currents}

The circulation near the seafloor obtained from the ROMS hydrodynamic model successfully simulates the main currents that are known in the Mozambique Channel: surface currents flowing southwards along the African continental margin at the surface and intermediate depths (Mozambique Current), and deep currents flowing northwards along the same margin (Mozambique Undercurrent) and back southwards along the western Madagascar margin (Fig. 7). The group of seamounts and islands present in the centre of the Mozambique Channel generate multiple topographic changes that result in a complex bottom circulation, forming gyres within small basins and around topographic highs (Fig. 7).

Hydrodynamic modelling results show strong currents flowing southwards along the western part of the Davie Ridge with mean speeds of $10-15 \mathrm{~cm} \mathrm{~s}^{-1}$ and maximum speeds of $30-55 \mathrm{~cm} \mathrm{~s}^{-1}$ (Fig. 7). The model also simulates intense currents along the Zambezi Valley, especially along the eastern flank, 
with maximum velocities of $40-60 \mathrm{~cm} \mathrm{~s}^{-1}$, and mean velocities of 8-18 $\mathrm{cm} \mathrm{s}^{-1}$ (Fig. 8), in agreement with the in situ measurements (Fig. 5). On the basin seafloor outside the valleys, simulated bottom currents are more intense to the west of the Zambezi Valley than to the east (towards the Madagascar margin). West of the Zambezi Valley mean velocities oscillate between 5 and $14 \mathrm{~cm} \mathrm{~s}^{-1}$ and maximum velocities between 15 and $50 \mathrm{~cm} \mathrm{~s}^{-1}$, while east of the Zambezi Valley, mean velocities are often around 3-5 $\mathrm{cm} \mathrm{s}^{-1}$ (reaching locally $13 \mathrm{~cm} \mathrm{~s}^{-1}$ ) and maximum velocities of about $15 \mathrm{~cm} \mathrm{~s}^{-1}$ (reaching locally $40 \mathrm{~cm} \mathrm{~s}^{-1}$ ) (Fig. 8). Modelling results also show intense bottom circulation around Europa Island, especially on the western and southern sides of the island, with mean velocities that can reach up to $18 \mathrm{~cm} \mathrm{~s}^{-1}$ and maximum velocities up to $70 \mathrm{~cm} \mathrm{~s}^{-1}$ (Fig. 8).

In order to better understand the observed changes in current direction and intensity at mooring sites, we calculated a composite of the Sea Level Anomaly (SLA), the bottom currents and the barotropic currents from the ROMS model for the periods of time during which currents at the mooring site MLP2 were above $25 \mathrm{~cm} \mathrm{~s}^{-1}$ (Fig. 9). The results show that during the periods of intense southward flow along the Zambezi Valley, the Mozambique Undercurrent is less intense, and there is an intensification of bottom currents flowing eastwards north and south of the group of islands and seamounts, and southwards along the Zambezi Valley (Fig. 9B). The composite of the SLA shows the presence of a large anticyclonic eddy (positive SLA) located between $21-24^{\circ} \mathrm{S}$ and $36-41^{\circ} \mathrm{E}$. The composite of barotropic currents (i.e. average of the currents in the whole water column) follows the eddy field, thus demonstrating that eddies are affecting the whole water column (Fig. 9C). The bottom current direction and zone of high intensity are generally coincident with the barotropic currents. However, the model results show a focusing of bottom currents along topographic reliefs such as the islands and seamounts, and the Zambezi Valley (Fig. 9).

\subsection{Evidence of contouritic sedimentation in the Zambezi turbidite system}

The Zambezi turbidite system is mainly composed of two valleys: the Zambezi Valley (U-shaped thalweg and V-shaped valley; Fierens et al., under review) originating from the Mozambican 
continental slope, and the Tsiribihina Valley originating from the western Madagascar slope (Figs. 1 and 2). Both valleys converge at about $22^{\circ} \mathrm{S}$, and the combined valley extends with a $\mathrm{N}-\mathrm{S}$ orientation until about $26^{\circ} \mathrm{S}$, where the depositional fan system starts to develop. Levees are absent along the main axis of the recent valleys and the flanks are often eroded (Fig. 3). The Zambezi Valley flanks are asymmetric, with more sediment accumulation east of the valley. The Tsiribihina Valley is more sinuous and narrower than the Zambezi Valley (Figs. 2 and 3). The flanks of the Zambezi Valley are covered by bedforms (Fig. 3). Sediment architectures similar to the Zambezi Valley flanks are observed in a purely contourite depositional system associated with a seamount near the Madagascar Ridge (Fig. 10). Elongated separated mounded drifts covered with large bedforms are separated from the seamounts by moats characterised by a flat homogeneous bottom (Fig. 10). The Serpa Pinto Valley used to act as the main conduit for terrigenous sediments in the Mozambique Channel until the Early Miocene (Droz and Mougenot, 1987). Despite being inactive, its relief can still be recognised on the present seafloor, and its sedimentary geometry shows similarities with the Zambezi Valley (Fig. 11). West of this valley the seafloor is dominated by an erosional surface and by large bedforms (Fig. 11).

Further evidence of bottom-current related features was obtained from two sediment piston cores (MOZO2-KSO6 and MOZ02-KS07) collected on the Zambezi Valley flanks about $60 \mathrm{~km}$ south of the confluence with the Tsiribihina Valley (Fig. 12), in areas with strong bottom currents according to the hydrodynamic modelling results (Fig. 8). The upper 0.80 (MOZ02-KSO7) and 1.75 metres (MOZO2KS06) of the sediment records are composed of foraminiferal sand (planktonic and benthic foraminifers), without clear lamination (Fig. 13). This area adjacent to the valley is characterised by high backscatter (Fig. 12C), in agreement with the sand sampled in cores (Fig. 13). The first centimetres of core MOZ02-KSO6 have been dated at 25,350 $\pm 240 \mathrm{cal}$ yr BP, and of core MOZ02KS07 at $11,648 \pm 284$ cal yr BP. According to the analysis of nannofossil assemblages of core MOZO2KS06, the foraminiferal sand began to be deposited 600-830 kyr ago (zone NN19-CN14a, absence of R. asanoi, at 1.69-1.70 m) (Fig. 13A). This allows the sedimentation rate to be estimated at about 0.2- 
$0.3 \mathrm{~cm} \mathrm{kyr}^{-1}$. Low sedimentation rates have also been observed in hemipelagic sediment in the vicinity of the Zambezi turbidite system. Sedimentation rates obtained by Fierens et al. (2017) at seven different sites for the last 248-718 kyr range between 0.5 and $2.4 \mathrm{~cm} \mathrm{kyr}^{-1}$ (Fig. 1B). The mudsand transition in core MOZ02-KSO6 is characterised by a hiatus. The age of the top of the mud unit (1.80-1.81 m) was estimated at 2.5-5 Ma (zones NN16-NN14). The foraminiferal sand layers display coarsening-up sequences, which are more marked in core MOZ02-KSO6. The volume of sand in these layers ranges between 54 and $89 \%$ in core MOZ02-KSO6 and between 45 and 70\% in core MOZO2KSO7 (Fig. 12). The increasing amount of carbonate sand in these layers is consistent with an increase in the XRF Ca/Fe ratio (due to a higher concentration of foraminifers) and in the $\mathrm{XRF} \ln (\mathrm{Zr} / \mathrm{Rb}$ ) ratio (due to the more energetic conditions and coarser grain size). Heavy minerals such as zircon can be accumulated due to winnowing under intense bottom currents (Bahr et al., 2014). The upper part of the muddy sequence in core MOZO2-KSO7 is characterised by burrows infilled with foraminifera sand from the upper sandy layer (Fig. 13B). This observation suggests that the sand could be contouritic. Contourites exhibit continuous and homogeneous bioturbation, while turbidites are mainly bioturbated from the top (Rodríguez-Tovar and Hernández-Molina, 2018). This interpretation is also supported by the observed inverse grading sequence (Fig. 13), which is typical of contourites (Rebesco et al., 2014, and references therein).

\section{Discussion}

\subsection{Modelled, observed and inferred circulation near the seafloor of the Mozambique Channel}

The ROMS hydrodynamic model successfully simulated bottom circulation in the Mozambique Channel in terms of speed and direction. The modelling results are in agreement with in situ measurements and directions inferred from morpho-sedimentary features recorded in previous studies.

The Agulhas Undercurrent (AUC) carries AAIW and NADW northwards below $700 \mathrm{~m}$ water depth along the southeast African continental slope, with speeds between 30 and $40 \mathrm{~cm} \mathrm{~s}^{-1}$ (Donohue et al., 
2000). The Mozambique Undercurrent (MUC) is the continuation of the AUC (Fig. 1A; Beal and Bryden, 1998). Ullgren et al. (2012) measured the MUC flowing northwards at $1500-2500 \mathrm{~m}$ water depth in a section at $37^{\circ} \mathrm{S}$, with mean speed below $4 \mathrm{~cm} \mathrm{~s}^{-1}$ and maximum values of $35 \mathrm{~cm} \mathrm{~s}^{-1}$. De Ruijter et al. (2002) reported that the MUC attains speeds ranging from 10 to $20 \mathrm{~cm} \mathrm{~s}^{-1}$. In the area studied by Ullgren et al. (2012) $\left(\sim 17^{\circ} \mathrm{S}\right)$ our model results show mean bottom currents of about 10 $\mathrm{cm} \mathrm{s}^{-1}$ and maximum speeds of $33-40 \mathrm{~cm} \mathrm{~s}^{-1}$ (Fig. 7), which is in agreement with in situ measurements. The modelling results show a southwards flow west of the Davie Ridge (Fig. 7) that has also been observed in the in situ measurements published by Ullgren et al. (2012).

Morpho-sedimentary features related to bottom currents also support the modelling results in the central and southern part of the Mozambique Channel in the depth range of the NADW (2000-3500 m water depth) and the AABW (below $3500 \mathrm{~m}$ ) (Fig. 1). An erosional surface and large bedforms were observed in the area of strong currents flowing southwards near the Davie Ridge (Figs. 7 and 11). This southward setting bottom current continues along the Zambezi Valley (Fig. 7), inducing the erosion of the V-shaped valley flank described by Fierens et al. (under review) (Figs. 3 and 12) and the deposition of contouritic sand (Fig. 13). Kolla et al. (1980) inferred current directions towards the south in the northern part of the Zambezi Valley and towards the north in the southern part of the valley, as observed in the in situ measurements described in the present study (Fig. 4). Kolla et al. (1980), Breitzke et al. (2017) and Wiles et al. (2017b) showed that bedforms are more abundant on the basin floor west of the Zambezi Valley than east of the valley. This asymmetric distribution of the bedforms is in agreement with the modelling results, which show stronger bottom currents on the basin floor west of the Zambezi Valley (Figs. 7 and 8). Moreover, the strong currents NW of Europa Island (Fig. 8) may explain the observed asymmetry of a carbonate levee system originating from the island, as documented by Counts et al. (2018).

The central part of the Mozambique Channel is characterised by the presence of multiple topographic highs and small basins (Fig. 1B). This bathymetric heterogeneity induces local changes in the bottom circulation, with the formation of gyres within the basins (e.g. in the basin southwest of 
the main group of seamounts and islands) and currents flowing around the topographic highs (e.g. northeast of the group of islands and seamounts) (Fig. 7). This bottom circulation pattern could be the cause of the arcuate and sub-circular bedforms observed by Breitzke et al. (2017) in this area.

In the southernmost part of the Mozambique Channel, the AABW flows northwards east of the Mozambique Ridge. It is then constrained to the north by the decreasing water depth, being forced to return southwards along the Madagascar Ridge (Figs. 1 and 7). The modelled current direction is once again in agreement with the inferred directions from morpho-sedimentary features and bottom photography described by Kolla et al. (1980) and Breitzke et al. (2017).

\subsection{Origin of intense bottom currents in the Zambezi Valley}

Anticyclonic rings in the Mozambique Channel have a large barotropic component, affecting the whole water column and reaching the bottom of the channel, as identified by velocity measurements and water properties (de Ruijter et al., 2002; Swart et al., 2010). Halo et al. (2014) showed that these large anticyclonic structures mainly propagate along the western edge of the Mozambique Channel. Hence, they would not directly affect the deep part of the Zambezi Valley. However, the presence of eddies may induce changes in the deep circulation pattern. Ullgren et al. (2012) correlated hydrographic properties at intermediate and greater depths with changes in current direction. Anticyclonic eddies passing through the narrowest part of the Mozambique Channel carry salty and warm RSW southwards, and thereby reduce or even revert the northward transport related to the Mozambique Undercurrent (Ullgren et al., 2012). They recognised that the meridional or vertical displacement of the water-mass interfaces induces rapid changes in temperature and salinity at fixed stations and that the end of the hydrographic changes (temperature and salinity) related to the velocity of the Mozambique Undercurrent is more abrupt than its onset. Similar variations have been observed in the mooring sites of the Zambezi Valley. The periods of intense currents are correlated with a change in current direction (southwards) and an increase in temperature (Fig. 6). The end of the warm water intrusion period is more abrupt than its onset. In some cases, such as in May 2016, 
the end of the event lasts only a few hours (Fig. 6). Modelling results show that during periods of intense southward currents at mooring site MLP2, a large anticyclonic ring is present at $21-24{ }^{\circ} \mathrm{S}$ between the African continental slope and the group of islands and seamounts in the centre of the Mozambique Channel (Fig. 9). Anticyclones can block the northward transport of the Mozambique Undercurrent along the Mozambican slope (Fig. 9; Ullgren et al., 2012). When the northward transport along the western part of the Mozambique Channel is limited, the southward NADW transport may increase along the Zambezi Valley (Fig. 9). This may induce a deepening of the interface between the NADW and the AABW at the Zambezi Valley (Fig. 14). The NADW-AABW interface would thus move southwards, and the mooring sites would detect an increase in temperature related to the warmer NADW compared to the AABW (Figs. 6 and 14). Intense southward setting currents are related to these changes in the water-mass properties (Fig. 7). Although the mooring duration is too short for a precise assessment, the occurrence of 7 events in a year is consistent with the eddy variability obtained from satellite altimetry by Schouten et al. (2003) and from the LOCO mooring by Harlander et al. (2009) and Ridderinkhof et al. (2010). This is also consistent with the frequency of occurrence of Mozambique Channel Rings obtained by Halo et al. (2014) from altimetry and two ocean models.

The effect of eddies on the seafloor may be direct: as in the Gulf of Cadiz, by generating sub-circular depressions (García et al., 2016), and in the NW Atlantic Ocean, by generating benthic nepheloid layers (Gardner et al., 2017); or indirect, as shown in the present study. Eddies can influence the deep circulation and induce periods of strong bottom currents that may erode the seafloor, winnow fine-grained sediment or generate furrows and large bedforms. Gardner et al. (2017) observed benthic storms (i.e. events of strong currents capable of eroding the seafloor and generating benthic nepheloid layers) in areas with high sea-surface eddy kinetic energy, related to the Gulf Stream or its associated rings. The importance of eddies in controlling deep-sea sedimentation is also supported by a global comparison of contourite distribution and hydrodynamic modelling, which showed that contourites are located in areas with high simulated bottom eddy kinetic energy (Thran et al., 2018). 
Shanmugam (2016) criticizes the use of the generic term contourite because of its broad sense that covers all the sediment affected by any bottom current, and suggests the use of a classification according to the different processes that generate the deposits: contourite for geostrophic currents, bottom-current reworked sands for wind-driven bottom currents, tidalite for tide-driven bottom currents, and baroclinite for internal waves or tide-driven baroclinic currents. But in the ocean, different processes are superimposed with different daily, seasonal and interannual frequencies. For instance, geostrophic currents in the Zambezi Valley are modulated in the frequency band of tides and anticyclones. It is very hard or almost impossible to relate a pure oceanographic process to a pure depositional facies. Therefore, we consider that the generic term contourite is appropriate for any sediment affected by bottom currents, although in contrast to the common definition of Rebesco et al. (2014) and references therein, bottom currents do not need to be persistent, their velocity may strongly vary, as shown in this study.

\subsection{Implications for source-to-sink studies}

Mixed contourite-turbidite systems are often characterised by an alternation of contouritic and turbiditic deposits, that result from variations in the dominant sedimentary process (Mulder et al., 2008). The Zambezi system is a particular mixed system dominated by erosive processes related to the oceanic circulation. The Zambezi Valley flanks are eroded (V-shaped), and levees are absent in most part of the system. Another particularity of the Zambezi mixed system is the absence of contourite drift-turbidite alternation, as observed in mixed systems of the southeastern Brazilian margin (Viana et al., 1999) or of the South China Sea (Zhu et al., 2010; He et al., 2013). In addition, no typical sediment drifts have been identified associated with the turbidite system, as described for example in Antarctica (Rebesco et al., 2002). At present, the circulation in the Mozambique Channel is probably too intense to allow the formation of large sediment drifts. The seafloor is characterised by erosive features such as furrows and irregular large-scale bedforms, especially west of the Zambezi Valley (Breitzke et al., 2017). Lower sediment accumulations west of the Zambezi Valley may 
also be related to stronger bottom currents that could prevent or reduce sediment deposition in this area, compared to the area east of the valley where weaker bottom currents would favour sediment accumulation (Figs. 3 and 8). Most of the sediments carried by turbidity currents are probably retransported by bottom currents at all depths, thus little fine-grained sediments would arrive as a gravity flow to the deep part of the basin.

Van Sebille et al. (2015) demonstrated that planktonic foraminifera shells could be transported off South Africa hundreds of kilometres before being deposited on the seafloor. They considered for the foraminifera shells a settling velocity of $0.23 \mathrm{~cm} \mathrm{~s}^{-1}$, that is much higher than the settling velocity of coarse silt $\left(0.1 \mathrm{~cm} \mathrm{~s}^{-1}\right)$ or fine silt $\left(0.01 \mathrm{~cm} \mathrm{~s}^{-1}\right)$ (Gibbs et al., 1971). Therefore, the fine-grained sediments could be transported in suspension by the eddies travelling southwards and be finally deposited outside the Mozambique Channel. Zhang et al. (2014) showed that surface-generated mesoscale eddies of the South China Sea can trap and transport sediment in suspension, influencing deep-water sedimentary processes.

The Zambezi Valley presents a low sinuosity (Wiles et al., 2017b), in contrast to most of the lowlatitude submarine channels that are characterised by high sinuosity due to a regular and stable sediment supply, usually composed of fine-grained material (Mulder, 2011; Peakall et al., 2012). This particularity of the Zambezi Valley may be caused by sediment sorting due to bottom currents before the formation of the turbidity current or during its movement. The NAMOC (Northwest Atlantic MidOcean Channel) in the Labrador Sea and the Tanzania channel in the Southwest Indian Ocean show similar characteristics to the Zambezi Valley: absence of well-developed aggradational levees, low sinuosity and flat erosive thalwegs (Hesse et al., 1987; Klaucke et al., 1998; Bourget et al., 2008; Wiles et al., 2017b). All these areas are under the influence of strong western boundary currents. For instance, the Eirik and Gloria Drifts are located in close vicinity to the NAMOC turbidite system (Klaucke et al., 1998), evidencing the effect of bottom currents in the area. The slope of North Mozambique-Tanzania is also well known for the interaction of contouritic and turbiditic processes. Palermo et al. (2014) interpreted the presence of channel and lobe complexes flanked by unilateral 
drift mounds in the Lower Eocene depositional sequence of the Rovuma Basin as the effect of bottom currents that would deviate the fine-grained suspension cloud of the turbidity currents. This process would remove part of the fine-grained sediments from the turbidity current, increasing the grain size composition of the turbidity current, and thus generating low sinuosity channels even at low latitudes.

\section{Conclusion}

In situ current measurements, obtained from 5 mooring stations in the Zambezi and Tsiribihina Valleys, and regional hydrodynamic modelling show that the circulation near the seafloor in the Mozambique Channel is very intense and may have an important impact on deep-sea sedimentation. The main conclusions of this study are:

(1) Measured mean bottom currents in the Zambezi and Tsiribihina Valleys at 3400-4050 m water depth are about 9-15 $\mathrm{cm} \mathrm{s}^{-1}$, but bottom currents show a high variability, with periods of intense circulation characterised by current speeds up to $53 \mathrm{~cm} \mathrm{~s}^{-1}$. The results of the ROMS hydrodynamic model show that bottom currents are accelerated along the V-shaped valley flanks, with velocities similar to the mooring data, and in agreement with the flank erosion observed in seismic profiles. The periods of intense current speed are correlated with a reversal of the current direction and with an increase in temperature. These events seem to be related to the eddy activity, since they present a similar frequency as the anticyclonic eddies (about 7 per year). Moreover, modelling results show that during the identified periods of intense bottom currents, an anticyclonic ring was present between the Mozambican slope and the centre of the Mozambique Channel. The anticyclone may induce a reduction of the northward transport of the Mozambique Undercurrent along the Mozambican margin. Therefore, the southward transport of North Atlantic Deep Water along the eastern part of the Mozambique Channel could be enhanced, deepening the interface between the North Atlantic Deep Water and the Antarctic Bottom Water, and generating increased bottom currents and temperature at the mooring sites. 
(2) Multibeam bathymetry and seismic reflection data show that the Zambezi turbidite system is mainly dominated by erosive processes: the Zambezi Valley flanks are eroded and covered in some areas by contouritic sand. Moreover, levees are absent in most of the system, and large zones with furrows and large bedforms are found in the vicinity of the turbidite system. The morphological characteristics of the Zambezi Valley (low sinuosity, absence of levees and a flat erosive U-shaped thalweg) are not typical of low latitude systems, which are usually mud-rich systems. The strong bottom currents present in the Mozambique Channel may transport away most of the fine-grained sediment carried in suspension by the turbidity currents, generating coarser and probably better sorted turbidity currents.

\section{Acknowledgments}

We thank the Captains, crews and onboard scientific teams of the PTOLEMEE, PAMELA-MOZO1 and PAMELA-MOZ02 surveys onboard the R/V L'Atalante, as well as the PAMELA-MOZO4 survey onboard the R/V Pourquoi pas? and the PAMELA-MOZ08 survey onboard the R/V Antea. The oceanographic surveys PTOLEMEE, PAMELA-MOZ01, PAMELA-MOZO2, PAMELA-MOZO4 and PAMELA-MOZ08, as well as Elda Miramontes' Post-Doctoral fellowship and Ruth Fierens' PhD are co-funded by TOTAL and IFREMER as part of the PAMELA (PAssive Margin Exploration Laboratories) scientific project. The PAMELA project is a scientific project led by Ifremer and TOTAL in collaboration with Université de Bretagne Occidentale, Université Rennes 1, Université Pierre and Marie Curie, CNRS and IFPEN.

\section{References}

Bahr, A., Jiménez-Espejo, F.J., Kolasinac, N., Grunert, P., Hernández-Molina, F.J., Röhl, U., Voelker, A.H.L., Escutia, C., Stow, D.A.V., Hodell, D., Alvarez-Zarikian, C.A., 2014. Deciphering bottom current velocity and paleoclimate signals from contourite deposits in the Gulf of Cádiz during the last 140 kyr: An inorganic geochemical approach. Geochemistry, Geophysics, Geosystems 15(8), 3145-3160. 
Beal, L.M., and H.L. Bryden, 1997. Observations of an Agulhas undercurrent, Deep Sea Research, 44, $1715-1724$.

Bourget, J., Zaragosi, S., Garlan, T., Gabelotaud, I., Guyomard, P., Dennielou, B., Ellouz-Zimmermann, N., Schneider, J.L., the FanIndien 2006 survey crew, 2008. Discovery of a giant deep-sea valley in the Indian Ocean, off eastern Africa: The Tanzania channel. Marine Geology 255(3), 179-185.

Breitzke, M., Wiles, E., Krocker, R., Watkeys, M.K., Jokat, W., 2017. Seafloor morphology in the Mozambique Channel: evidence for long-term persistent bottom-current flow and deep-reaching eddy activity. Marine Geophysical Research 38(3), 241-269.

Calvès, G., Toucanne, S., Jouet, G., Charrier, S., Thereau, E., Etoubleau, J., Marsset, T., Droz, L., Bez, M., Abreu, V., Jorry, S., Mulder, T., Lericolais, G., 2013. Inferring denudation variations from the sediment record; an example of the last glacial cycle record of the Golo Basin and watershed, East Corsica, western Mediterranean sea. Basin Research, 25(2), 197-218.

Castelino, J.A., Reichert, C., Jokat, W., 2017. Response of Cenozoic turbidite system to tectonic activity and sea-level change off the Zambezi Delta. Mar Geophys Res. doi:10.1007/s11001-0179305-8.

Counts, J. W., Jorry, S. J., Leroux, E., Miramontes, E., Jouet, G., 2018. Sedimentation adjacent to 523 atolls and volcano-cored carbonate platforms in the Mozambique Channel (SW Indian Ocean). 524 Marine Geology 404, 41-59.

Courgeon, S., Jorry, S.J., Camoin, G.F., BouDagher-Fadel, M.K., Jouet, G., Révillon, S., Bachèlery, P., Pelleter, E., Borgomano, J., Poli, E., Droxler, A.W., 2016. Growth and demise of Cenozoic isolated carbonate platforms: New insights from the Mozambique Channel seamounts (SW Indian Ocean). Marine Geology 380, 90-105.

Covault, J.A., Romans, B.W., Graham, S.A., Fildani, A., Hilley, G.E., 2011. Terrestrial source to deepsea sink sediment budgets at high and low sea levels: insights from tectonically active southern California. Geology 39, 619-622. 
de Ruijter, W.P.M., Ridderinkhof, H., Lutjeharms, J.R.E., Schouten, M.W., Veth, C., 2002. Observations of the flow in the Mozambique Channel. Geophysical Research Letters 29(10), http://dx.doi.org/10.1029/2001GL013714.

Debreu, L., Marchesiello, P., Penven, P., Cambon, G., 2012. Two-way nesting in split-explicit ocean models: algorithms, implementation and validation, Ocean Model. 49-50, 1-21.

DiMarco, S.F., Chapman, P., Nowlin, W.D. Jr, Hacker, P., Donohue, K., Luther, M., Johnson and G.C., Toole, J., 2002. Volume transport and property distributions of the Mozambique Channel. DeepSea Res II (Topical Studies in Oceanography), 49, 1481-1511.

Donohue, K.A., Firing, E., Beal, L., 2000. Comparison of three velocity sections of the Agulhas Current and Agulhas Undercurrent. Journal of Geophysical Research: Oceans, 105(C12), 28585-28593.

Droz, L., Mougenot, D., 1987. Mozambique Upper Fan: Origin of depositional units. AAPG Bulletin 71, 1355-1365.

Fierens, R., Droz, L., Toucanne, S., Jorry, S., Raisson, F., 2017. Plio-Quaternary sedimentation in the Mozambique Channel and in the Zambezi Fan. In EGU General Assembly Conference Abstracts, $19,7520$.

Fierens, R., Droz, L., Toucanne, S., Raisson, F., Jouet, G., Babonneau, N., Landurain, S., Jorry, S.J., under review. Subsurface geomorphology of the Zambezi turbidite system from new bathymetric and sub-bottom profiler data. Geomorphology.

Flemming, B.W. and Kudrass, H., 2018. Large dunes on the outer shelf off the Zambezi Delta, Mozambique: evidence for the existence of a Mozambique Current. Geo-Marine Letters, 38, 95105.

García, M., Hernández-Molina, F.J., Alonso, B., Vázquez, J.T., Ercilla, G., Llave, E., Casas, D., 2016. Erosive sub-circular depressions on the Guadalquivir Bank (Gulf of Cadiz): Interaction between bottom current, mass-wasting and tectonic processes. Marine Geology 378, 5-19. 
Gardner, W.D., Tucholke, B.E., Richardson, M.J., Biscaye, P.E., 2017. Benthic storms, nepheloid layers, and linkage with upper ocean dynamics in the western North Atlantic. Marine Geology 385, 304327.

Gibbs, R.J., Matthews, M.D., Link, D.A., 1971. The relationship between sphere size and settling velocity. Journal of sedimentary research $41(7), 7-18$.

Giraudeau, J., Christensen, B.A., Hermelin, O., Lange, C.B., Motoyama, I., Shipboard Scientific Party, 1998. Biostratigraphic age models and sedimentation rates along the southwest African margin. In: Proceedings of the Ocean Drilling Program Initial Reports, (Eds. G. Wefer, W.H. Berger, C. Richter), 175, pp. 543-546.

Gordon, A.L., 1986. Inter-ocean exchange of thermocline water. Geophysical Research Letters 91, $5037-5046$.

Halo, I., Backeberg, B., Penven, P., Ansorge, I., Reason, C., Ullgren, J.E., 2014. Eddy properties in the Mozambique Channel: A comparison between observations and two numerical ocean circulation models. Deep Sea Research Part II: Topical Studies in Oceanography 100, 38-53.

Harlander, U., Ridderinkhof, H., Schouten, M. W., De Ruijter, W. P. M., 2009. Long-term observations of transport, eddies, and Rossby waves in the Mozambique Channel. Journal of Geophysical Research: Oceans 114(C2).

He, Y., Xie, X., Kneller, B. C., Wang, Z., Li, X., 2013. Architecture and controlling factors of canyon fills on the shelf margin in the Qiongdongnan Basin, northern South China Sea. Marine and Petroleum Geology 41, 264-276.

Helland-Hansen, W., Sømme, T.O., Martinsen, O.J., Lunt, I., Thurmond, J., 2016. Deciphering earth's natural hourglasses: perspectives on source-to-sink analysis. Journal of Sedimentary Research 86(9), 1008-1033.

Hernández-Molina, F. J., Soto, M., Piola, A. R., Tomasini, J., Preu, B., Thompson, P., Badalini, G., Creaser, A., Violante, R.A., Morales, E., Paterlini, M., De Santa Ana, H., 2016. A contourite 
depositional system along the Uruguayan continental margin: Sedimentary, oceanographic and paleoceanographic implications. Marine Geology 378, 333-349.

Hernández-Molina, F. J., Campbell, S., Badalini, G., Thompson, P., Walker, R., Soto, M., Conti, B., Preu, B., Thieblemont, A., Hyslop, L., Miramontes, E., Morales, E., 2017. Large bedforms on contourite terraces: Sedimentary and conceptual implications. Geology 46, 27-30.

Hesse, R., Chough, S.K., Rakofsky, A., 1987. The Northwest Atlantic Mid-Ocean Channel of the Labrador Sea. V. sedimentology of a giant deep-sea channel. Canadian Journal of Earth Sciences 24(8), 1595-1624.

Jorry, S., 2014. PTOLEMEE cruise, RV L'Atalante, http://dx.doi.org/10.17600/14000900.

Jorry, S. J., Camoin, G. F., Jouet, G., Le Roy, P., Vella, C., Courgeon, S., Prat, S., Fontanier, C., Paumard, V., Boulle, J., Caline, B., Borgomano, J., 2016. Modern sediments and Pleistocene reefs from isolated carbonate platforms (Iles Eparses, SW Indian Ocean): A preliminary study. Acta oecologica, 72, 129-143.

Jouet, G., Deville, E., 2015. PAMELA-MOZ04 cruise, RV Pourquoi pas?, http://dx.doi.org/10.17600/15000700.

Khripounoff, A., 2017. PAMELA-MOZ08 cruise, RV Antea, http://dx.doi.org/10.17600/17003900.

Klaucke, I., Hesse, R., Ryan, W.B.F., 1998. Seismic stratigraphy of the Northwest Atlantic Mid-Ocean Channel: growth pattern of a mid-ocean channel-levee complex. Marine and Petroleum Geology 15(6), 575-585.

Kolla, V., Eittreim, S., Sullivan, L., Kostecki, J.A., Burckle, L.H., 1980. Current-controlled, abyssal microtopography and sedimentation in Mozambique Basin, Southwest Indian Ocean. Marine Geology 34, 171-206.

Lutjeharms, J.R.E., 2006. The Agulhas Current, Vol. 1. Springer-Verlag, Berlin.

Mahanjane, E.S., 2014. The Davie Fracture Zone and adjacent basins in the offshore Mozambique Margin-A new insights for the hydrocarbon potential. Marine and Petroleum Geology 57, 561571. 
Mantyla, A.W., and Reid, J.L., 1995. On the origins of deep and bottom waters of the Indian Ocean. Journal of Geophysical Research: Oceans 100(C2), 2417-2439.

Miramontes, E., Jorry, S.J., Jouet, G., Counts, J.W., Courgeon, S., Le Roy, P., Guerin, C., HernándezMolina, F.J., accepted. Deep marine dunes on drowned isolated carbonate terraces (Mozambique Channel, SW Indian Ocean). Sedimentology, https://doi.org/10.1111/sed.12572.

Mulder, T., 2011. Gravity processes and deposits on continental slope, rise and abyssal plains. In: Hüneke, H., Mulder, T. (Eds.), Deep-sea Sediments, Developments in Sedimentology, 63. Elsevier, Amsterdam, pp. 25-148.

Mulder, T., Faugères, J.C., Gonthier, E., 2008. Mixed turbidite-contourite systems. In: Rebesco, M., Camerlenghi, A. (Eds.), Contourites. Developments in Sedimentology, 60. Elsevier, Amsterdam, pp. 435-456.

Olu, K., 2014. PAMELA-MOZ01 cruise, RV L’Atalante, http://dx.doi.org/10.17600/14001000.

Palermo, D., Galbiati, M., Famiglietti, M., Marchesini, M., Mezzapesa, D., Fonnesu, F., 2014. Insights into a New Super-Giant Gas Field - Sedimentology and Reservoir Modeling of the Coral Complex, Offshore Northern Mozambique. Offshore Technology Conference Asia, Malaysia: OTC-24907-MS, 1-8.

Peakall, J., Kane, I.A., Masson, D.G., Keevil, G., McCaffrey, W.D., Corney, R., 2012. Global (latitudinal) variation in submarine channel sinuosity. Geology $40,11-14$.

Pujos, A. (1988). Spatio-temporal distribution of some Quaternary coccoliths. Oceanologica Acta, 11, 65-77.

Quartly, G.D., de Cuevas, B.A. and Coward, A.C., 2013. Mozambique Channel eddies in GCMs: a question of resolution and slippage. Ocean Modelling, 63, 56-67.

Reale, V., and Monechi, S., 2005. Distribution of the calcareous nannofossil Reticulofenestra asanoi within the Early-Middle Pleistocene transition in the Mediterranean Sea and Atlantic Ocean: correlation with magneto-and oxygen isotope stratigraphy. Geological Society, London, Special Publications, 247, 117-130. 
Rebesco, M., Pudsey, C., Canals, M., Camerlenghi, A., Barker, P., Estrada, F., Giorgetti, A., 2002. Sediment drift and deep-sea channel systems, Antarctic Peninsula Pacific Margin. In: Stow, D.A.V., Pudsey, C.J., Howe, J.A., Faugères, J.C., Viana, A.R. (Eds.), Deepwater Contourite Systems: Modern Drifts and Ancient Series, Seismic and Sedimentary Characteristics. Geological Society, London, Memoirs, 22, pp. 353-371.

Rebesco, M., Hernández-Molina, F.J., Van Rooij, D.,Wåhlin, A., 2014. Contourites and associated sediments controlled by deep-water circulation processes: State-of-the-art and future considerations. Marine Geology 352, 111-154.

Reimer, P.J., Bard, E., Bayliss, A., Beck, J.W., Blackwell, P.G., Ramsey, C.B., Buck, C.E., Cheng, H., Edwards, R.L., Friedrich, M., Grootes, P.M., Guilderson, T.P., Haflidason, H., Hajdas, I., Hatte, C., Heaton, T.J., Hoffmann, D.L., Hogg, A.G., Hughen, K.A., Kaiser, K.F., Kromer, B., Manning, S.W., Niu, M., Reimer, R.W., Richards, D.A., Scott, E.M., Southon, J.R., Staff, R.A., Turney, C.S.M., van der Plicht, J., 2013. IntCal13 and Marine13 radiocarbon age calibration curves 0-50,000 years cal BP. Radiocarbon 55, 1869-1887.

Ridderinkhof, H., van der Werf, P.M., Ullgren, J.E., van Aken, H.M., van Leeuwen, P.J., de Ruijter, W.P.M., 2010. Seasonal and interannual variability in the Mozambique Channel from moored current observations. Journal of Geophysical Research: Oceans 115(C6), http://dx.doi.org/10.1029/2009JC005619.

Robin, C., Droz, L., 2014. PAMELA-MOZ02 cruise, RV L'Atalante, http://dx.doi.org/10.17600/14001100.

Rodríguez-Tovar, F.J., Hernández-Molina, F.J., 2018. Ichnological analysis of contourites: Past, present and future. Earth-science reviews, 28-41.

Romans, B.W., Castelltort, S., Covault, J.A., Fildani, A., Walsh, J.P., 2016. Environmental signal propagation in sedimentary systems across timescales. Earth-Science Reviews 153, 7-29.

Sato, T., Kameo, K. and Takayama, T. (1991). Coccolith biostratigraphy of the Arabian Sea. In: Proceedings of the Ocean Drilling Program. Scientific Results, Oman Margin/Neogene Package: 
Covering Leg 117 of the Cruises of the Drilling Vessel JOIDES Resolution, Port Louis, Mauritius, to Port Louis, Mauritius, Sites 720-731, 19 August 1987-17 October 1987 (Eds. Prell, W.L., Niitsuma, N., et al.), 117, 37-54.

Schott, F. A., S.-P. Xie, J. P. McCreary, Jr., 2009. Indian Ocean circulation and climate variability. Reviews of Geophysics 47, RG1002.

Schouten, M.W., de Ruijter, W.P., Van Leeuwen, P.J., Ridderinkhof, H., 2003. Eddies and variability in the Mozambique Channel. Deep Sea Research Part II: Topical Studies in Oceanography 50(12-13), 1987-2003.

Schulz, H., Lückge, A., Emeis, K., Mackensen, A., 2011. Variability of Holocene to Late Pleistocene Zambezi riverine sedimentation at the upper continental slope off Mozambique, $15^{\circ}-21^{\circ} \mathrm{S}$. Marine Geology 286, 21-34.

Shanmugam, G., 2016 The Contourite Problem. In: Mazumder, R. (Ed.). Sediment Provenance. Elsevier, 2016, pp. 193-253.

Shchepetkin, A.F., and McWilliams, J.C., 2005. The regional oceanic modeling system (ROMS): a splitexplicit, free-surface, topography-following-coordinate oceanic model. Ocean Model 9, 347-404.

Sømme, T.O., Helland-Hansen, W., Martinsen, O.J., Thurmond, J.B., 2009. Relationships between morphological and sedimentological parameters in source-to-sink systems: a basis for predicting semi-quantitative characteristics in subsurface systems. Basin Research 21, 361-387.

Swart, N.C., Lutjeharms, J.R.E., Ridderinkhof, H., de Ruijter, W.P.M., 2010. Observed characteristics of Mozambique Channel eddies. Journal of Geophysical Research: Oceans 115(C9), http://dx.doi.org/10.1029/2009JC005875.

Thierstein, H.R., Geitzenauer, K., Molfino, B., and Shackleton, N.J. (1977). Global synchroneity of late Quaternary coccolith datum levels: validation by oxygen isotopes. Geology, 5, 400-404.

Thran, A.C., Dutkiewicz, A., Spence, P., Müller, R.D., 2018. Controls on the global distribution of contourite drifts: Insights from an eddy-resolving ocean model. Earth and Planetary Science Letters 489, 228-240. 
Tew-Kai, E., and Marsac, F., 2009. Patterns of variability of sea surface chlorophyll in the Mozambique Channel: a quantitative approach. Journal of Marine Systems 77(1-2), 77-88.

Ullgren, J.E., van Aken, H.M., Ridderinkhof, H., de Ruijter, W.P.M., 2012. The hydrography of the Mozambique Channel from six years of continuous temperature, salinity, and velocity observations. Deep Sea Research Part I: Oceanographic Research Papers 69, 36-50.

van Aken, H.M., Ridderinkhof, H., de Ruijter, W.P.M., 2004. North Atlantic deep water in the southwestern Indian Ocean. Deep-Sea Res. I 51, 755-776.

van Sebille, E., Scussolini, P., Durgadoo, J.V., Peeters, F.J., Biastoch, A., Weijer, W., Turney, C., Paris, C.B., Zahn, R., 2015. Ocean currents generate large footprints in marine palaeoclimate proxies. Nature communications 6, 6521.

Viana, A.R., Almeida, J.W., Machado, L.C., 1999. Different styles of canyon infill related to gravity and bottom current processes: Example from the upper slope of the SE Brazilian margin. Publicaçao Sexto Congresso International da Sociedade Brasileira de Geofisica, SBGF 014, 4 pp.

Walford, H., White, N., Sydow, J., 2005. Solid sediment load history of the Zambezi Delta. Earth Planet. Sci. Lett. 238, 49e63. http://dx.doi.org/10.1016/j.epsl.2005.07.014.

Weatherall, P., Marks, K. M., Jakobsson, M., Schmitt, T., Tani, S., Arndt, J.E., Rovere, M., Chayes, D., Ferrini, V., Wigley, R., 2015. A new digital bathymetric model of the world's oceans, Earth and Space Science 2, 331-345.

Weaver, P.P.E., 1993. High resolution stratigraphy of marine Quaternary sequences. Geological Society, London, Special Publications, 70, 137-153.

Weijer, W., de Ruijter, W.P.M., Dijkstra, H.A., van Leeuwen, P.J., 1999. Impact of Interbasin Exchange on the Atlantic Overturning Circulation. Journal of Physical Oceanography 29, 2266-2284.

Wiles, E., Green, A., Watkeys, M., Jokat, W., 2017a. Zambezi continental margin: compartementalized sediment transfer routes to the abyssal Mozambique Channel. Marine Geophysical Research 38, 227-240. 
Wiles, E., Green, A., Watkeys, M., Jokat, W., 2017b. The Zambezi Channel: a new perspective on submarine channel evolution at low latitudes. Geomorphology 286, 121-132.

Zhang, Y., Liu, Z., Zhao, Y., Wang, W., Li, J., Xu, J., 2014. Mesoscale eddies transport deep-sea sediments. Scientific reports 4, 5937.

Zhang, W., Hanebuth, T.J.J., Stober, U., 2016. Short-term sediment dynamics on a meso-scale contourite drift (off NW Iberia): Impacts of multi-scale oceanographic processes deduced from the analysis of mooring data and numerical modelling. Marine Geology 378, 81-100.

Zhu, M., Graham, S., Pang, X., McHargue, T., 2010. Characteristics of migrating submarine canyons from the middle Miocene to present: implications for paleoceanographic circulation, northern South China Sea. Marine and Petroleum Geology 27(1), 307-319.

\section{FIGURES CAPTIONS}

Fig. 1. (A) Bathymetry of the South East Indian Ocean (GEBCO and PAMELA cruises) showing the main circulation patterns (based on van Aken et al., 2004 and Schott et al., 2009). AUC: Agulhas Undercurrent; MC: Mozambique Current; MUC: Mozambique Undercurrent; SEC: South Equatorial Current; NEMC: Northeast Madagascar Current; SEMC: Southeast Madagascar Current; Moz-C: Mozambique Channel; Moz-B: Mozambique Basin. (B) Zoom of the Mozambique Channel bathymetry. The blue dots represent the Conductivity Temperature Depth (CTD) profiles used in Fig. 1C. The mean sedimentation rates $\left(\mathrm{cm} \mathrm{kyr}^{-1}\right)$ over the last $248-718 \mathrm{kyr}$, obtained from the sediment cores and represented with red stars, are also indicated. (C) Salinity section along the Zambezi Valley showing the distribution of the main water masses present in the area, based on CTD profiles located in 1B. (D) Potential temperature-salinity diagram showing the different water masses present in the Mozambique Channel. $\sigma_{0}$ : potential density anomaly $\left(\mathrm{kg} \mathrm{m}^{-3}\right)$; TSW: Tropical Surface Water; STSW: Sub-Tropical Surface Water; SICW: South Indian Central Water; AAIW: Antarctic Intermediate Water; RSW: Red Sea Water; NADW: North Atlantic Deep Water; AABW: Antarctic Bottom Water. 
Fig. 2. Slope map obtained from the PAMELA project multibeam bathymetry and GEBCO bathymetry showing the location (and depth) of the moorings. See location in Fig. 1B.

Fig. 3. Multi-channel seismic reflection profiles (A) PTO-SR-785 and PTO-SR-685; (B) MOZ2-SR-13B; showing the location of the moorings MLP2, MLP3, MLP5 and MLP10. Moorings MLP5 and MLP10 are projected on the seismic profile since they are located $13 \mathrm{~km}$ north of the profile. See location in Fig. 2.

Fig. 4. Rose diagrams of current direction at $15 \mathrm{~m}$ above the seafloor at mooring sites MLP2, MLP3, MLP5, MLP8 and MLP10. The colours represent the current speed and the dark blue lines the orientation of the valley axis at the mooring sites. See Fig. 2 for mooring location.

Fig. 5. Time series of the current speed at $15 \mathrm{~m}$ above the seafloor at mooring sites MLP2, MLP3, MLP5, MLP8 and MLP10. See Fig. 2 for mooring location and colour codes.

Fig. 6. Time series of the current speed and current direction measured at mooring site MLP8 at $15 \mathrm{~m}$ above the seafloor, temperature measured at the same mooring at $30 \mathrm{~m}$ above the seafloor, and sediment flux from a sediment trap located at $40 \mathrm{~m}$ above the seafloor. See Fig. 2 for mooring location.

Fig. 7. Bottom circulation in the Mozambique Channel simulated from 1993 to 2014 with the Regional Ocean Modelling System (ROMS) model: (A) Maximum speed. The black dots indicate the location of the mooring sites; (B) Mean speed. The schematic arrows represent the mean bottom current directions obtained from the hydrodynamic model. Depth contours are shown every $500 \mathrm{~m}$. MC: Mozambique Current; MUC: Mozambique Undercurrent. The red arrows represent the current direction inferred from seafloor photographs by Kolla et al. (1980).

Fig. 8. Zoom of the simulated bottom circulation at the Zambezi turbidite system: (A) Bathymetry and vectors of the mean bottom current velocity. The arrow size is proportional to the speed and the orientation to the current direction; (B) Maximum speed; (C) Mean speed. Contours of the model bathymetry are shown every $200 \mathrm{~m}$. See Fig. 7 for location. 
Fig. 9. (A) Mean bottom currents obtained from the ROMS model for the period 1993-2014. (B) Composite of bottom currents obtained from the periods during which bottom currents at the mooring site MLP2 (indicated with a green dot) are above $25 \mathrm{~cm} \mathrm{~s}^{-1}$, and composite of the Sea Level Anomaly (SLA) during these periods of time (red and blue contours). SLA contours (red and blue lines) for the same period of time are indicated every $1 \mathrm{~cm}$. The blue contours indicate cyclones $(S L A<0)$ and the red contours anticyclones $(S L A>0)$. (C) Composite of barotropic currents (vertical average of the currents) during the same period of time as (B). SLA is also indicated. Bathymetric contours are indicated every $1000 \mathrm{~m}$.

Fig. 10. Moats and sediment drifts related to seamounts near the Madagascar Ridge. (A) Bathymetric map (Gebco 2008 and PAMELA multibeam bathymetric data). See Fig. 1A for location. (B) Multichannel seismic reflection profile MOZ2-SR-21B (location in A).

Fig. 11. Multi-channel seismic reflection profile MOZ4-SR-024 showing current-related features such as large bedforms and erosional surfaces in the vicinity of the Serpa Pinto Valley. See Fig. 7 for location.

Fig. 12. Location of cores MOZO2-KSO6 and MOZO2-KSO7 on (A) multi-channel seismic reflection profile PTO-SR-002, (B) multibeam bathymetry and (C) backscatter image of the Zambezi Valley, showing high backscatter at the core sites. See Fig. 2 for location of B and C.

Fig. 13. Grain size distribution, sand content, XRF $\mathrm{Ca} / \mathrm{Fe}$ ratio and XRF nepierian logarithm of the $\mathrm{Zr} / \mathrm{Rb}$ ratio of cores (A) MOZ02-KSO6 and (B) MOZ02-KS07. The ages shown with red arrows were obtained from radiocarbon dating and from nannofossil assemblages. The photo shows in real colour the mud to contouritic sand transition in core MOZO2-KS07. See Fig. 12 for core location.

Fig. 14. 3D sketch of the circulation in the Mozambique Channel. (A) Common circulation pattern with part of the North Atlantic Deep Water (NADW) flowing northwards along the Mozambican margin as part of the Mozambique Undercurrent, and part flowing back southwards along the eastern part of the basin. (B) Circulation pattern when an anticyclonic eddy is located between the Mozambican slope and the group of islands and seamounts in the centre of the Mozambique 
Channel, resulting in the intensification of the southward NADW transport, and deepening of the NADW and the Antarctic Bottom Water (AABW) interface. 


\section{Highlights}

- In situ measurements and modelling show strong currents along the Zambezi Valley

- Measured bottom currents in the Zambezi and Tsiribihina Valleys reach $53 \mathrm{~cm} \mathrm{~s}^{-1}$

- Eddies block the Mozambique Undercurrent, enhancing southward flow along the valley

- Bottom currents erode the Zambezi Valley flanks and control its morphology 

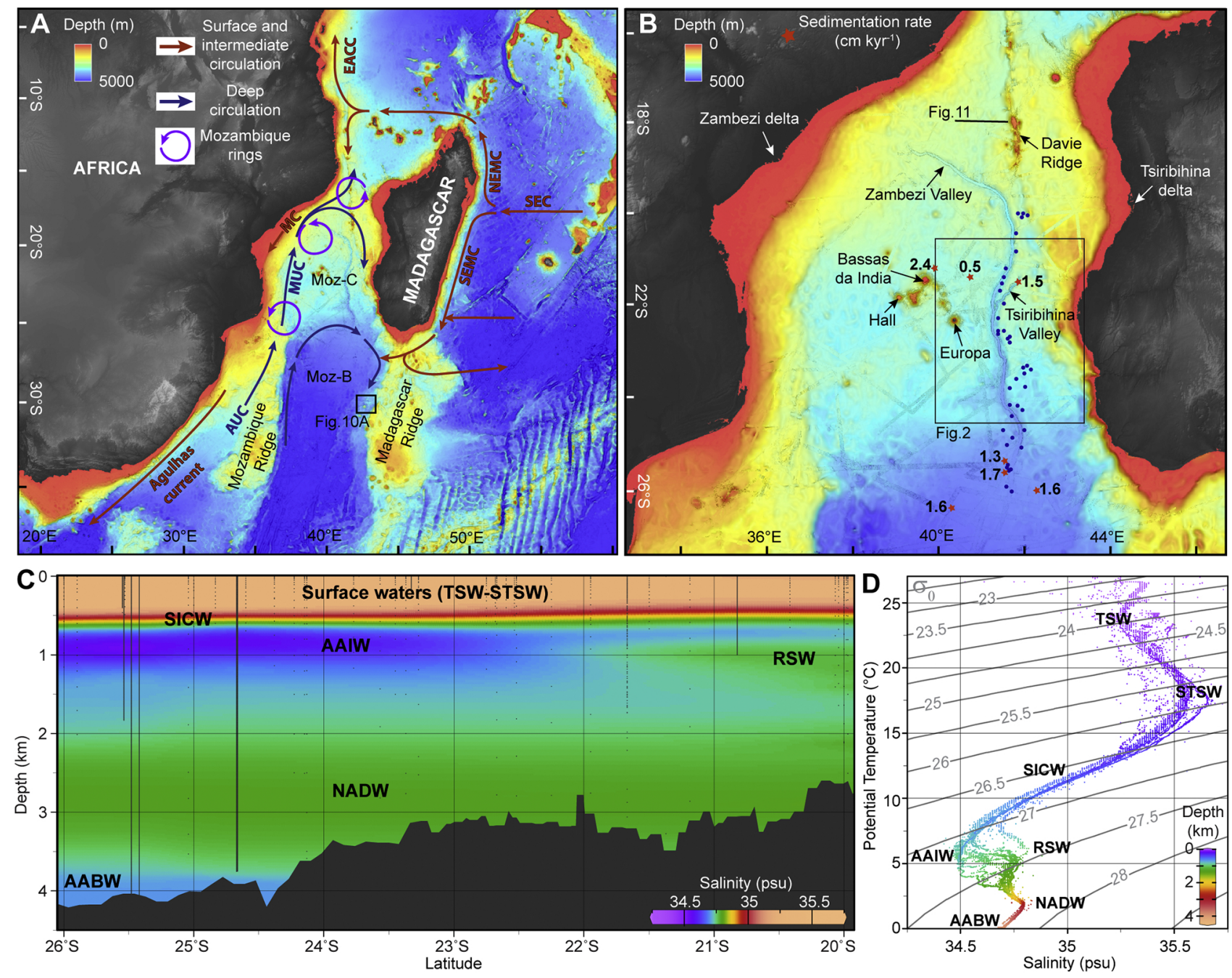

Figure 1 


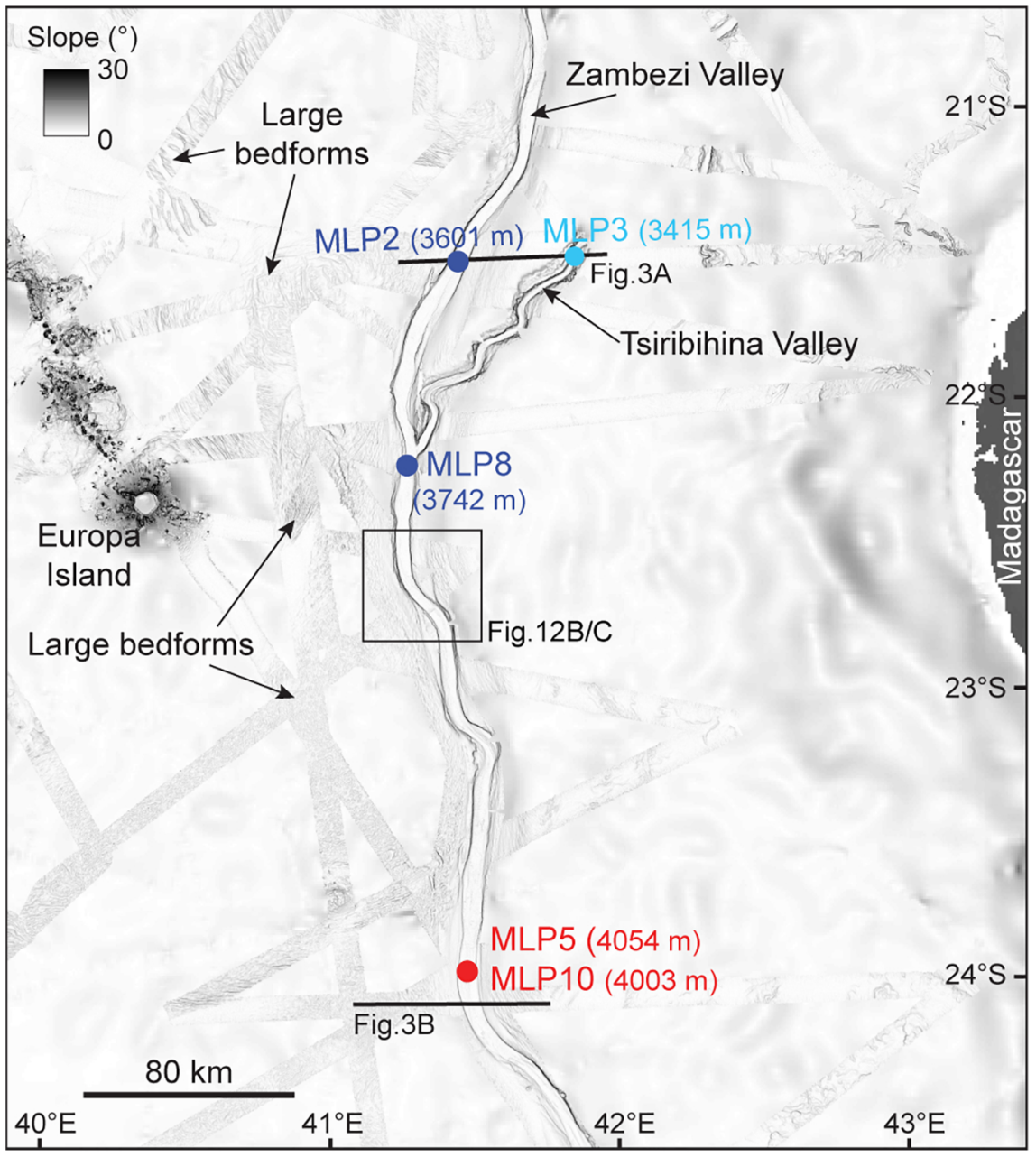

Figure 2 

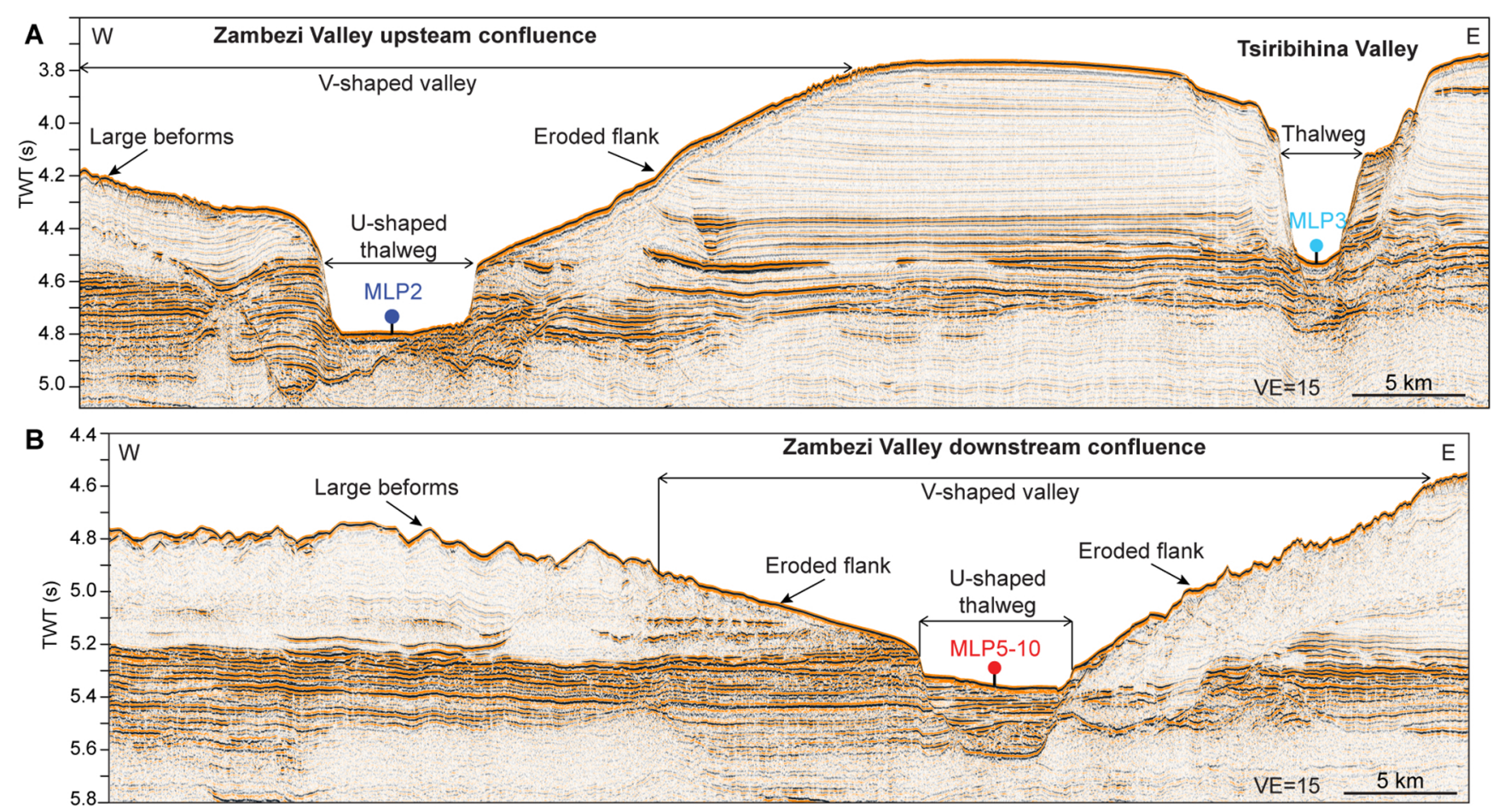

Figure 3 


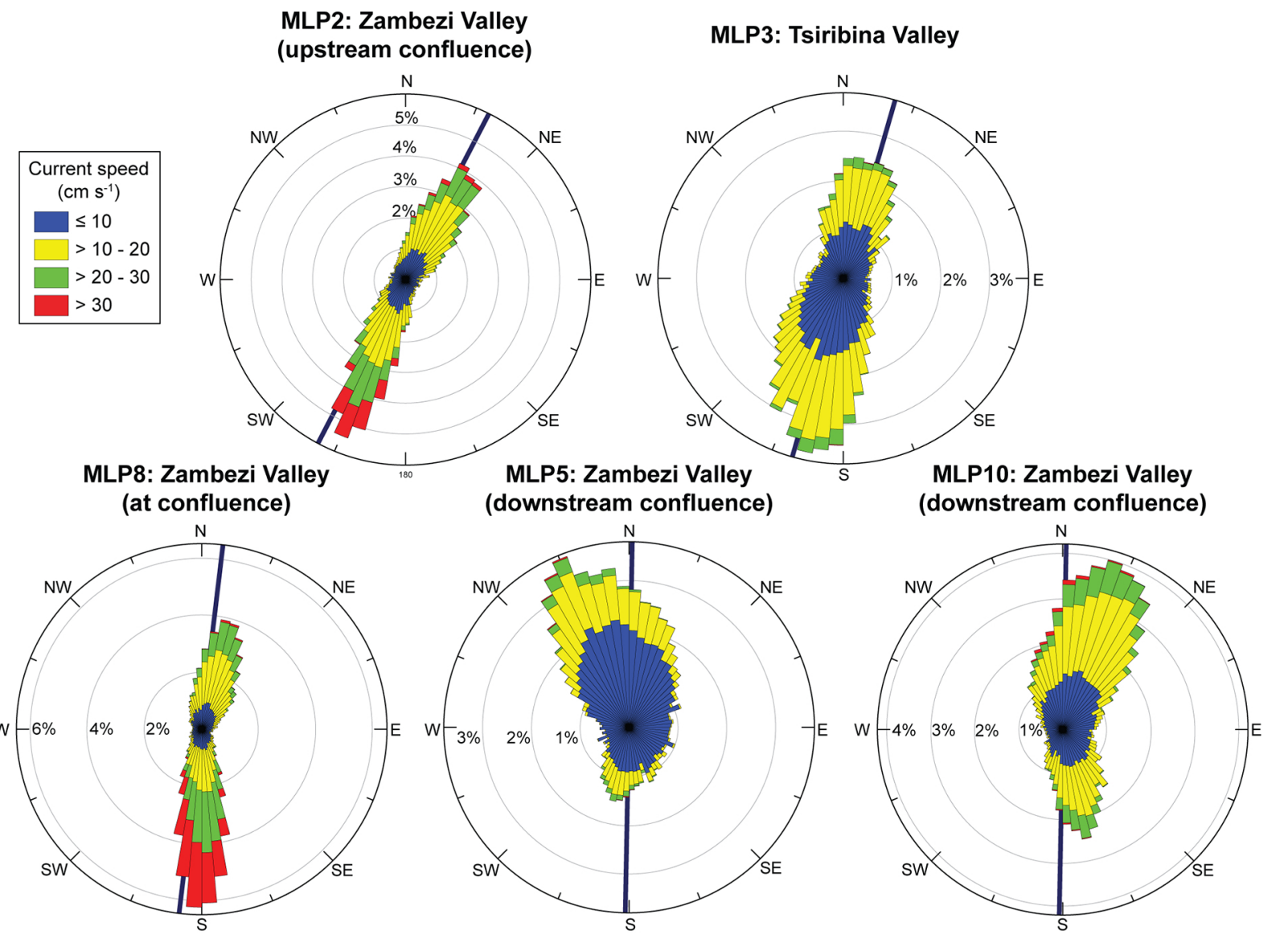

Figure 4 


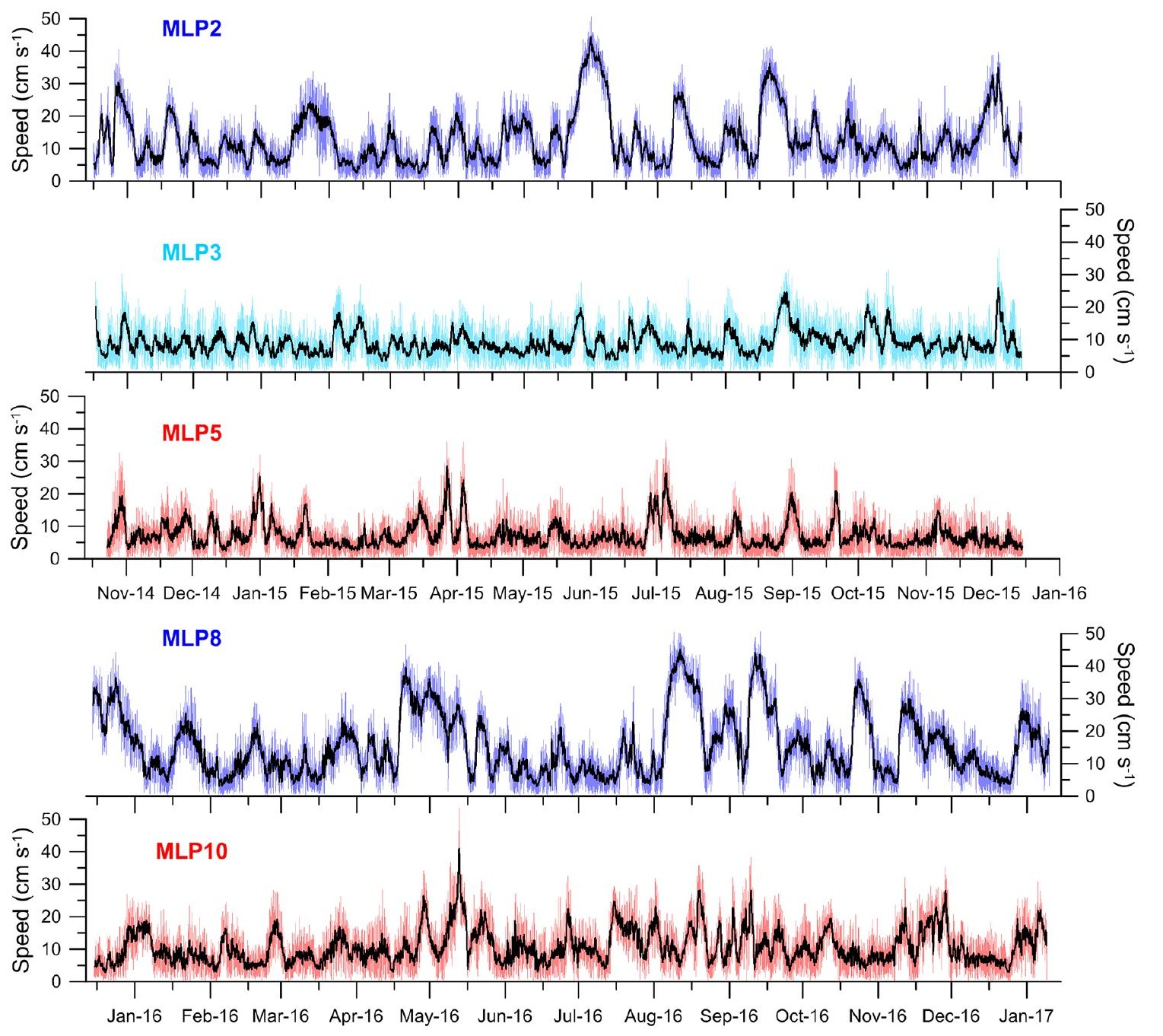

Figure 5 


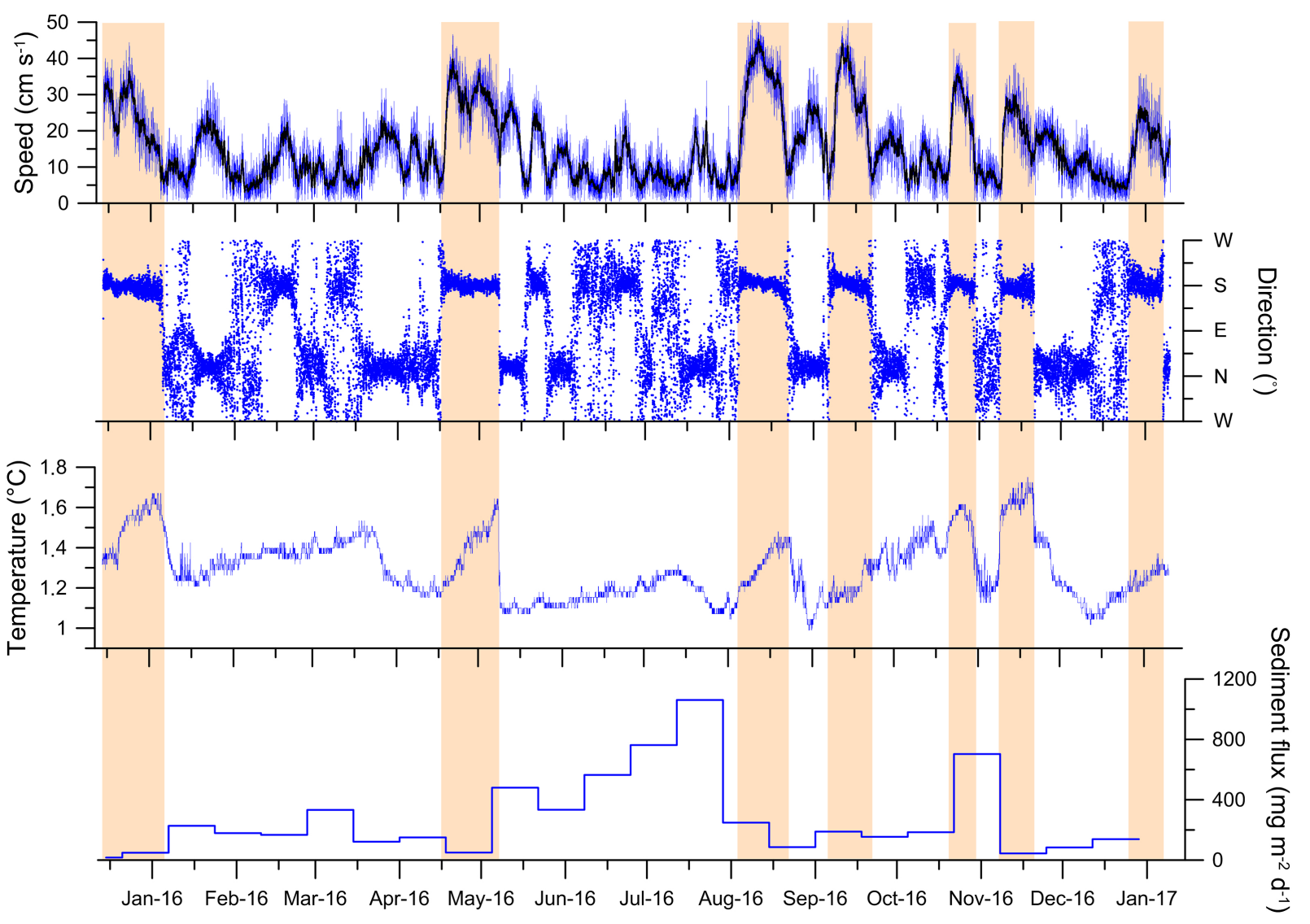

Figure 6 


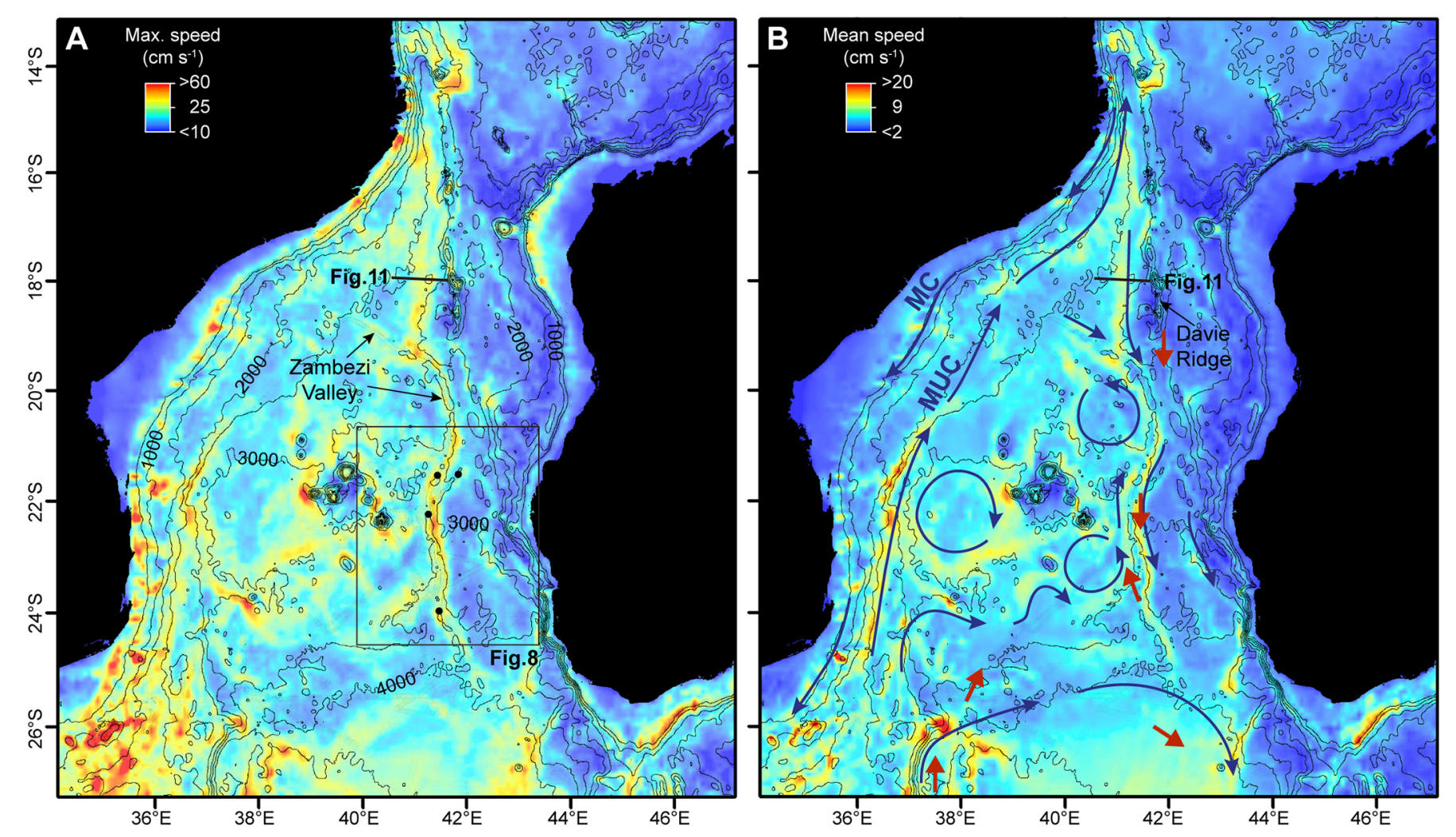

Figure 7 


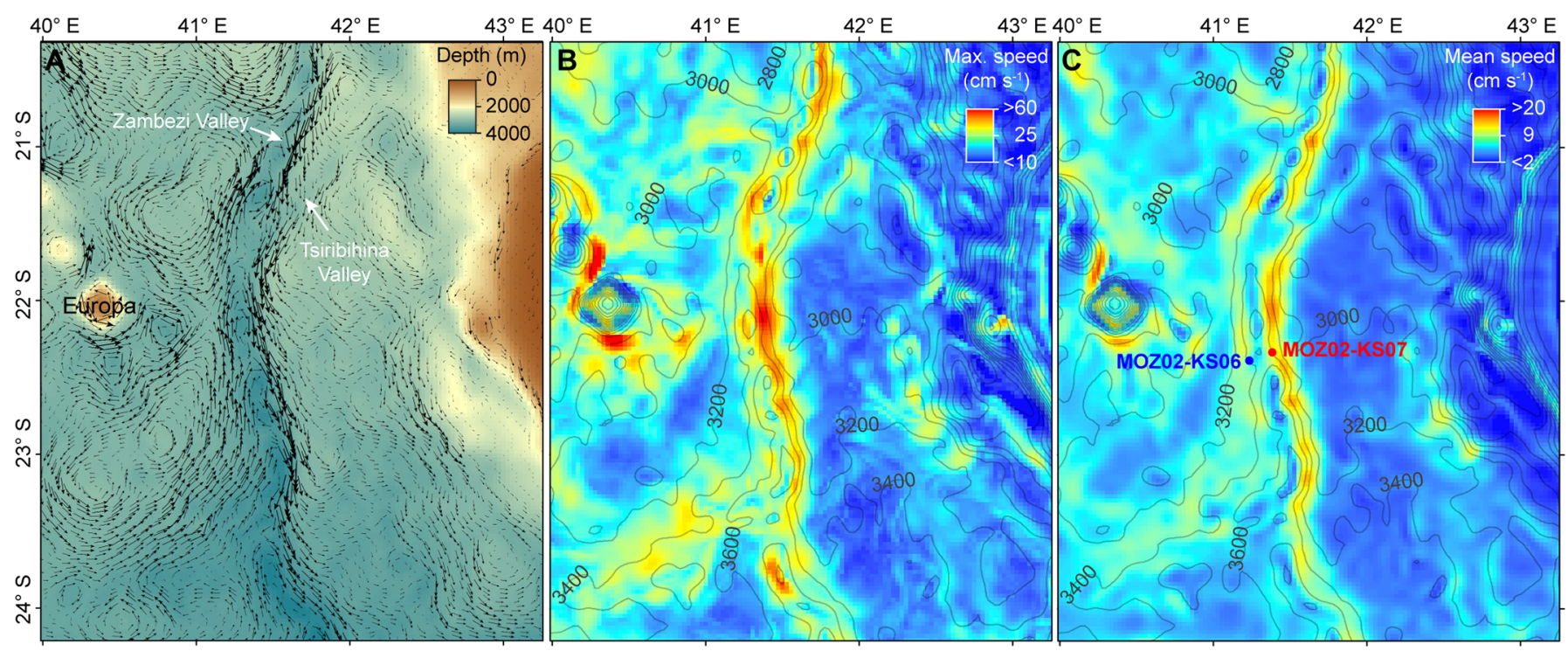

Figure 8 


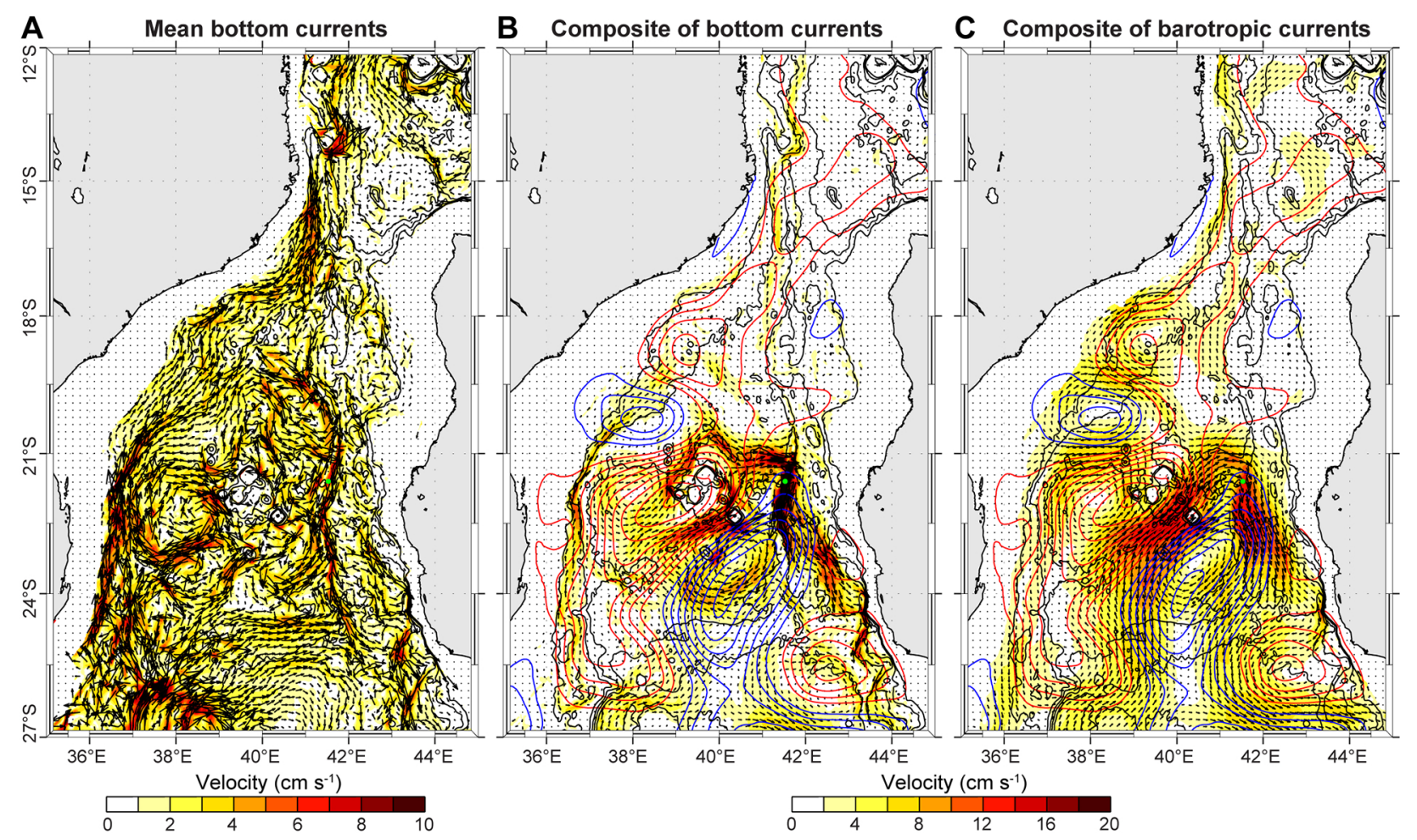

Figure 9 


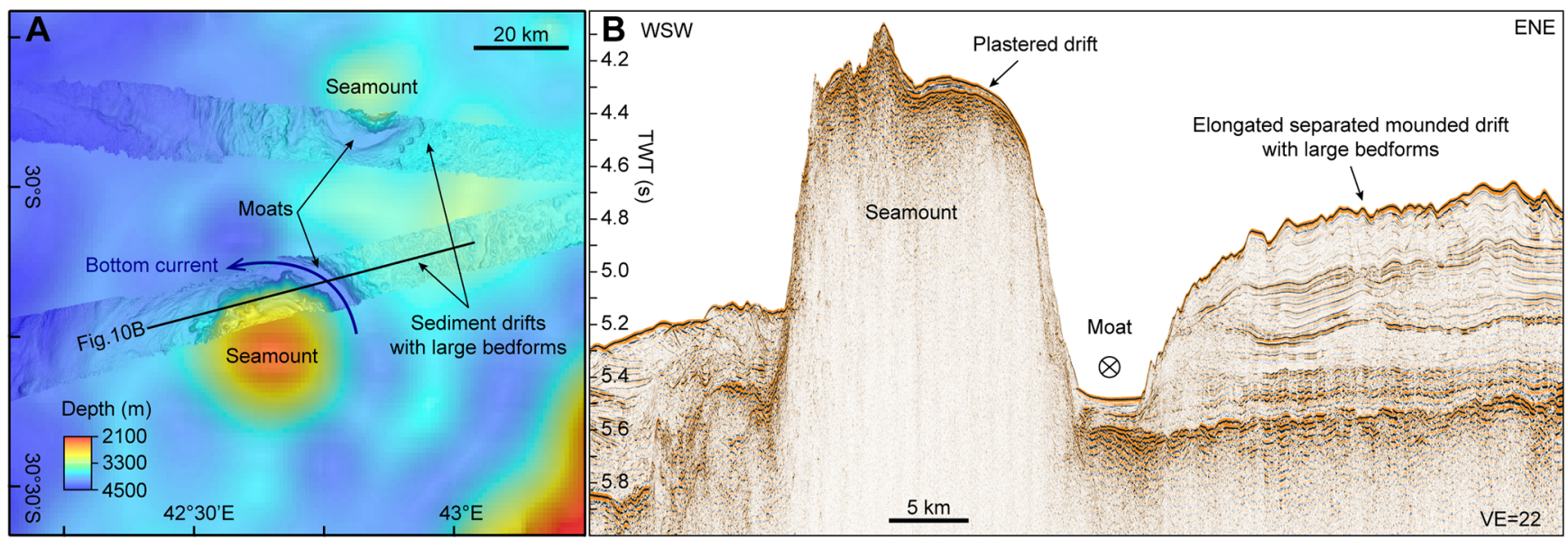




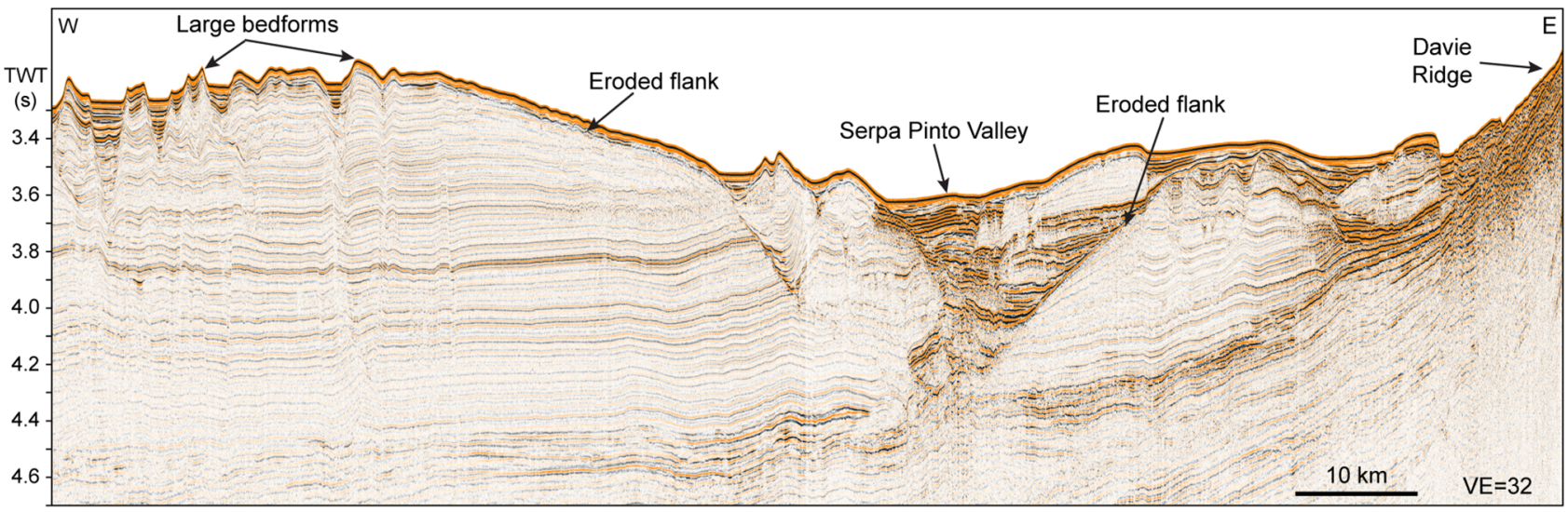

Figure 11 


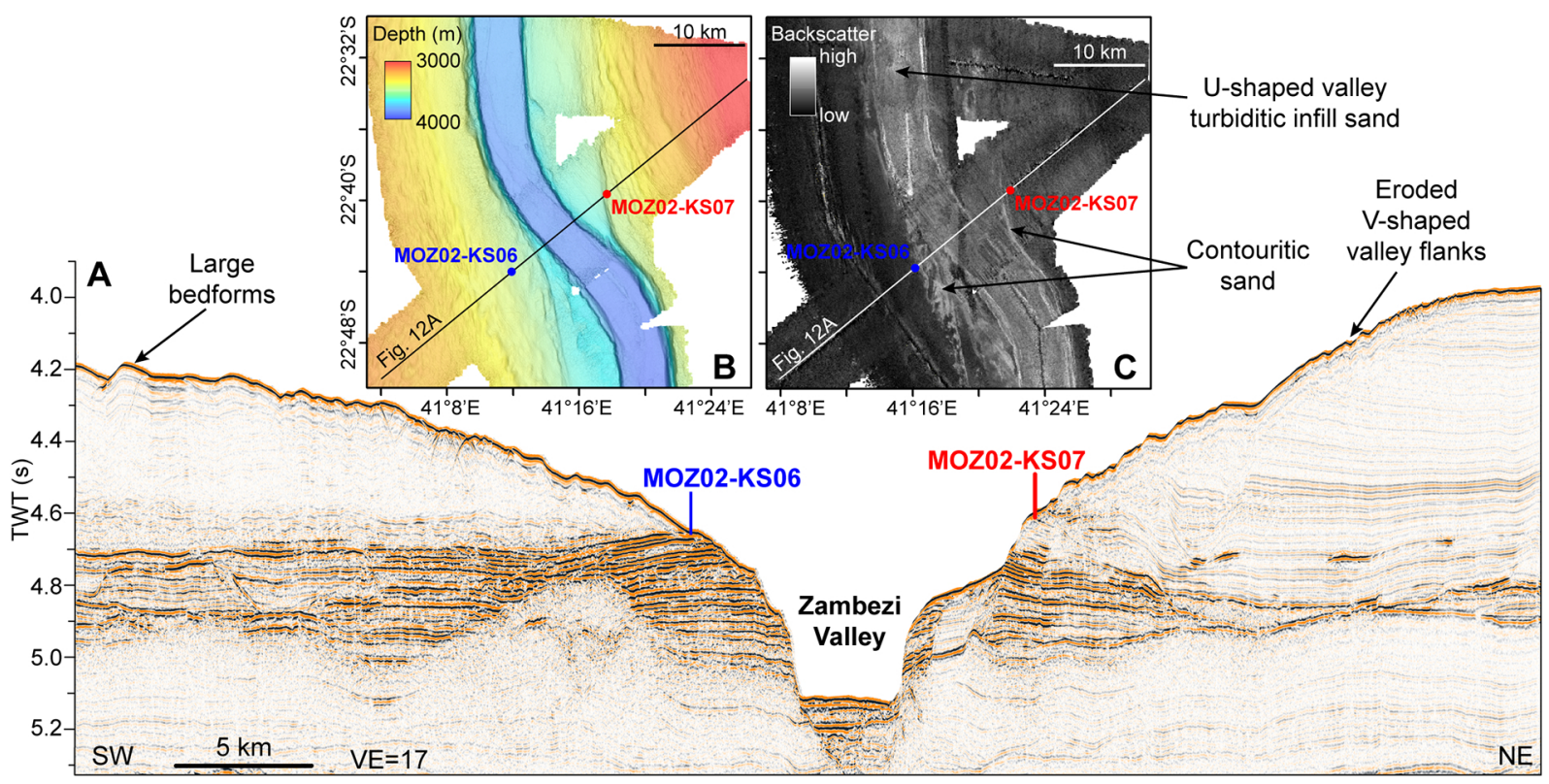

Figure 12 


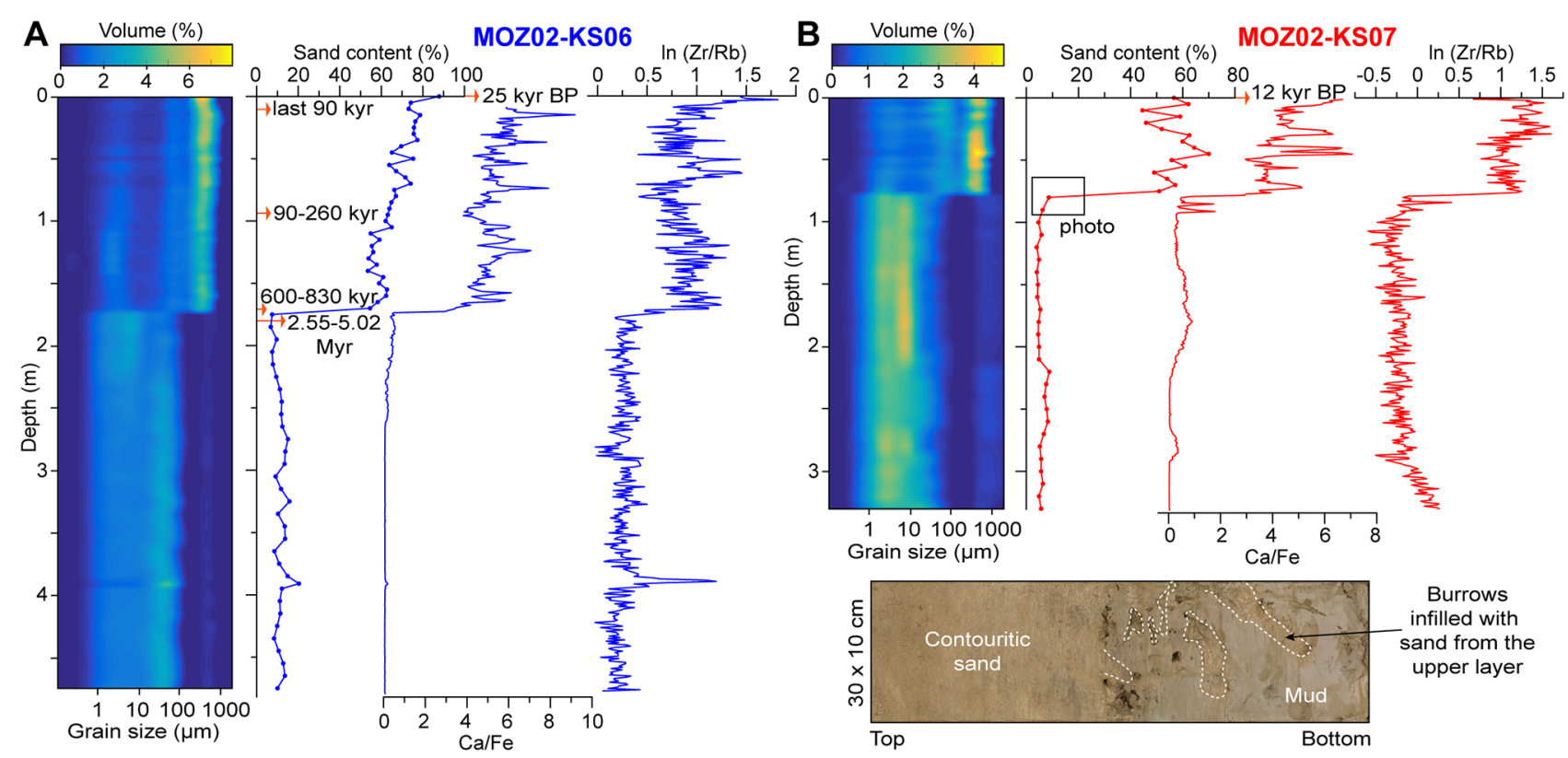




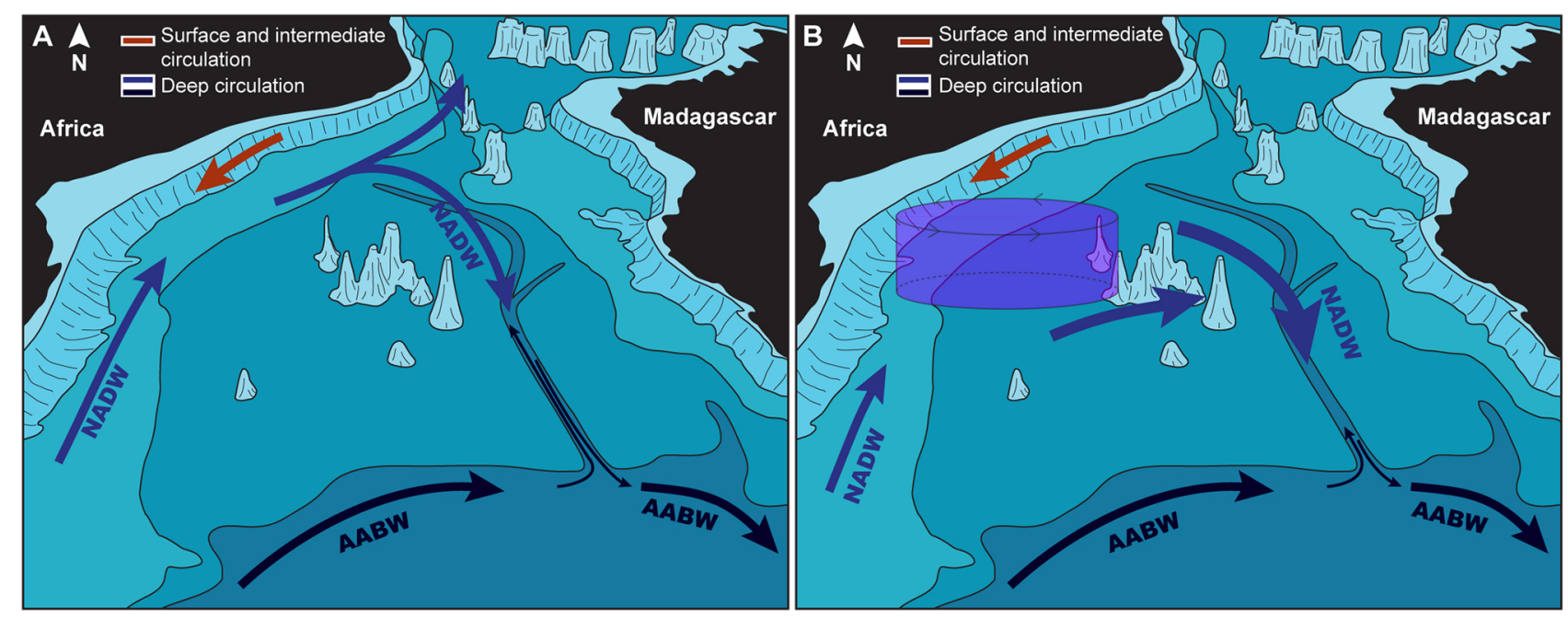

Figure 14 